\title{
Multi-year assimilation of IASI and MLS ozone retrievals: variability of tropospheric ozone over the tropics in response to ENSO
}

\author{
Hélène Peiro $^{1}$, Emanuele Emili ${ }^{1}$, Daniel Cariolle ${ }^{1,2}$, Brice Barret $^{3}$, and Eric Le Flochmoën ${ }^{3}$ \\ ${ }^{1}$ CECI, Université de Toulouse, Cerfacs, CNRS, Toulouse, France \\ ${ }^{2}$ Météo-France, Toulouse, France \\ ${ }^{3}$ Laboratoire d'Aérologie, Université de Toulouse, CNRS, UPS, Toulouse, France
}

Correspondence: Hélène Peiro (peiro@ cerfacs.fr)

Received: 15 September 2017 - Discussion started: 15 November 2017

Revised: 15 April 2018 - Accepted: 20 April 2018 - Published: 17 May 2018

\begin{abstract}
The Infrared Atmospheric Sounder Instrument (IASI) allows global coverage with very high spatial resolution and its measurements are promising for longterm ozone monitoring. In this study, Microwave Limb Sounder (MLS) $\mathrm{O}_{3}$ profiles and IASI $\mathrm{O}_{3}$ partial columns $(1013.25-345 \mathrm{hPa})$ are assimilated in a chemistry transport model to produce 6-hourly analyses of tropospheric ozone for 6 years (2008-2013). We have compared and evaluated the IASI-MLS analysis and the MLS analysis to assess the added value of IASI measurements.

The global chemical transport model MOCAGE (MOdèle de Chimie Atmosphérique à Grande Echelle) has been used with a linear ozone chemistry scheme and meteorological forcing fields from ERA-Interim (ECMWF global reanalysis) with a horizontal resolution of $2^{\circ} \times 2^{\circ}$ and 60 vertical levels. The MLS and IASI $\mathrm{O}_{3}$ retrievals have been assimilated with a 4-D variational algorithm to constrain stratospheric and tropospheric ozone respectively. The ozone analyses are validated against ozone soundings and tropospheric column ozone (TCO) from the OMI-MLS residual method. In addition, an Ozone ENSO Index (OEI) is computed from the analysis to validate the TCO variability during the ENSO events.

We show that the assimilation of IASI reproduces the variability of tropospheric ozone well during the period under study. The variability deduced from the IASI-MLS analysis and the OMI-MLS measurements are similar for the period of study. The IASI-MLS analysis can reproduce the extreme oscillation of tropospheric ozone caused by ENSO events over the tropical Pacific Ocean, although a correction is re-
\end{abstract}

quired to reduce a constant bias present in the IASI-MLS analysis.

\section{Introduction}

Tropospheric ozone $\left(\mathrm{O}_{3}\right)$ is the third most important greenhouse gas (Houghton et al., 2001). It influences the atmospheric radiative forcing as one of the main absorbers of infrared and ultraviolet radiation (Wang et al., 1980; Lacis et al., 1990). It also has a strong effect on human health and vegetation. High levels of $\mathrm{O}_{3}$ concentrations increase pulmonary and chronic respiratory diseases, increasing human premature mortality (Guilbert, 2003; Bell et al., 2004; Ebi and McGregor, 2008). High concentrations of $\mathrm{O}_{3}$ reduce photosynthesis and other important physiological functions of vegetation (Yendrek et al., 2015). Due to its relatively long lifetime $(\sim 2$ weeks in the troposphere), the global variability of tropospheric ozone is the combination of the complex interactions between anthropogenic emissions, chemical production and destruction, long-range transport, and stratosphere-troposphere exchanges. A global increase in tropospheric ozone has been documented during the last 30 years (Cooper et al., 2014), the cause of which is not yet well understood (Fowler et al., 2008). To determine the origin of this trend, it is important to evaluate the relative contributions between natural variability and anthropogenic forcing.

Among the natural forcings, the El Niño Southern Oscillation (ENSO) is an atmospheric phenomenon with a large- 
scale circulation pattern that influences the $\mathrm{O}_{3}$ distribution (Chandra et al., 1998; Zeng and Pyle, 2005) with a periodicity of about 2-7 years. ENSO refers to two events in the tropical Eastern Pacific: El Niño (anomalously warm ocean temperatures) and La Niña (anomalously cold ocean temperatures). ENSO is the dominant source of the tropical Pacific variability for the atmosphere and the ocean (Trenberth, 1997; Philander, 1989). During ENSO, changes in sea-surface temperatures (SSTs) in the Pacific Ocean have a large influence on the normal atmospheric circulation, displacing the location of convection and its intensity (Quan et al., 2004). These changes in circulation impact the temperature and moisture fields across the tropical Pacific, influencing the chemical composition of the troposphere (Ziemke and Chandra, 2003; Randel and Thompson, 2011, Fig. 1).

Convection during ENSO affects tropical tropospheric $\mathrm{O}_{3}$ in two ways. First, convection impacts the vertical mixing of $\mathrm{O}_{3}$ itself. Convection lifts lower tropospheric air masses with a low ozone concentration, where $\mathrm{O}_{3}$ lifetime is shorter, to upper troposphere where $\mathrm{O}_{3}$ lifetime is longer (Doherty et al., 2005). Overall increased convection leads to a decrease in the tropospheric ozone column (Fig. 1a). Second, convection affects vertical mixing and vertical distribution of $\mathrm{O}_{3}$ precursors (Stevenson et al., 2005). El Niño events coincide with dry conditions generating large-scale biomass burning in Indonesia (Chandra et al., 2002). During El Niño, TCO over Indonesia is higher than average. A remarkable change in the tropospheric $\mathrm{O}_{3}$ concentration due to El Niño occurred in the western part of Pacific during 1997-1998, with an increase in the TCO of +20 to $+25 \mathrm{DU}$ (Chandra et al., 2002). Atmospheric particulates and $\mathrm{O}_{3}$ precursors increase in Indonesia (Fig. 1b). During La Niña events, dry conditions are located in South America, causing an increase of TCO in the eastern Pacific Ocean (Fig. 1c).

Previous studies have characterized the variations of the tropical tropospheric $\mathrm{O}_{3}$ linked to ENSO (Ziemke et al., 2015). To characterize the ENSO amplitude several ENSO indices have been proposed based on ENSO footprints on the pressure field or the outgoing longwave radiation (Ardanuy and Lee Kyle, 1985; Trenberth, 1997). Ziemke et al. (2010) developed such an index for Ozone, the Ozone ENSO Index (OEI), to better characterize the effect of the oscillation on the $\mathrm{O}_{3}$ distribution and as a diagnostic tool for tropospheric chemistry models.

A detailed analysis of the effects of convection on tropospheric $\mathrm{O}_{3}$ has been prevented so far by the paucity of observations (Solomon et al., 2005; Lee et al., 2010). The restricted number of ozonesonde observations limits analysis of the links between $\mathrm{O}_{3}$ and ENSO (Thompson et al., 2003). Satellite observations can give more information on the $\mathrm{O}_{3}$ variability, and their global coverage gives better insight into the processes involved in ENSO (Ziemke et al., 2010). To derive tropospheric $\mathrm{O}_{3}$ several studies have combined ozone measurements from the Ozone Monitoring Instrument (OMI) that measures the total ozone columns, and the Microwave

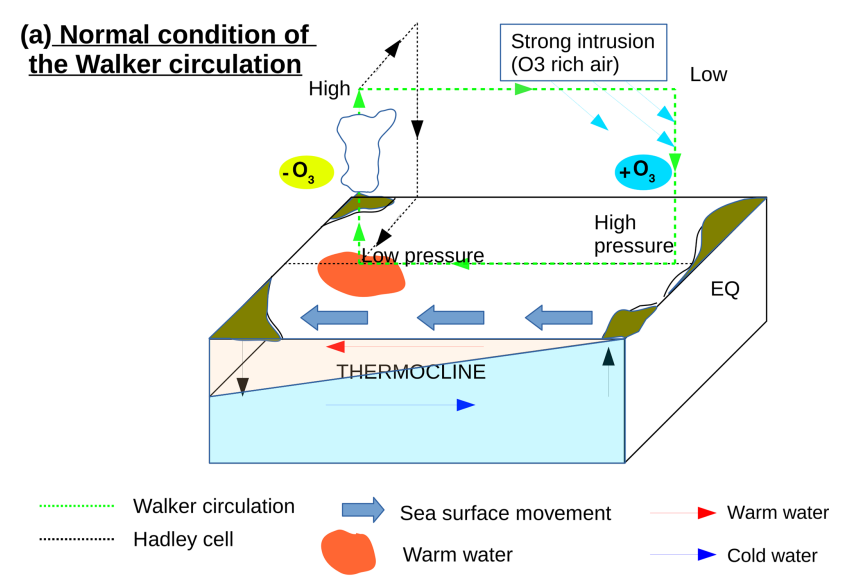

(b) El Niño condition : ocean surface warmer than average

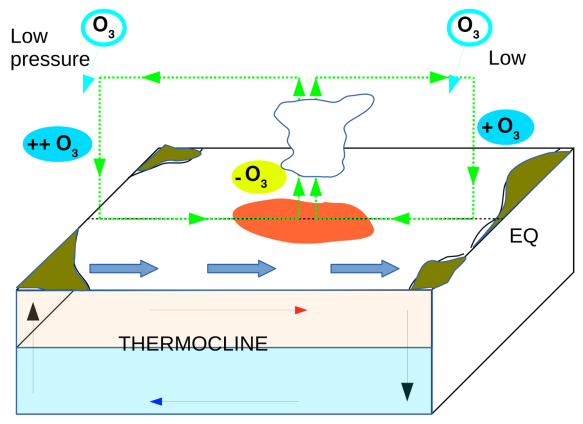

(c) La Niña condition : ocean surface cooler than average

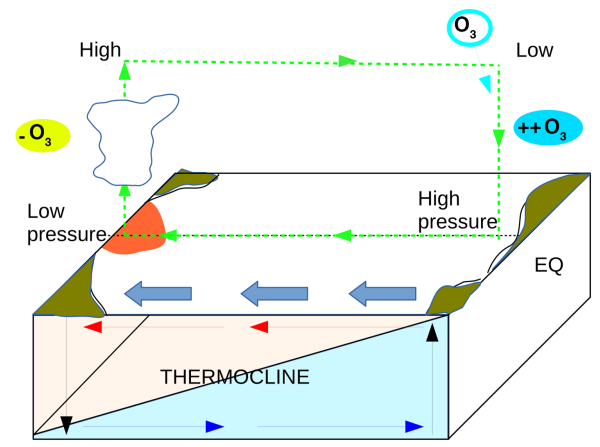

Figure 1. Schematic of the Walker circulation over the Pacific ocean. (a) During normal conditions: trade winds induce subsidence along South America with intrusion of $\mathrm{O}_{3}$-rich air. The TCO is elevated. In addition, along Indonesia, warmer waters generate convergence that results in low $\mathrm{O}_{3}$ concentrations. The TCO is weakened (b) during El Niño events: easterly trade winds are weakened. Therefore, convergence areas are located near the coast of South America while subsidence zones are located in the Indonesia. Low TCO is located over the Pacific ocean while high TCO is located over Indonesia, and (c) during La Niña events: during exceptionally strong trade winds the convergence over the Indonesia is stronger. The TCO has the lowest value. Subsidence over South America brings air masses with high $\mathrm{O}_{3}$ concentration, resulting in higher TCO than average values. 
Limb Sounder (MLS) that provides vertical ozone profiles in the upper troposphere and stratosphere. Ziemke et al. (2006) subtracted the stratospheric column $\mathrm{O}_{3}$ (of MLS) from the total column $\mathrm{O}_{3}$ (of OMI) to obtain the tropospheric column $\mathrm{O}_{3}$ (named hereafter OMI-MLS). They show a large impact of ENSO on tropospheric $\mathrm{O}_{3}$ in the tropics by analyzing the OMI-MLS data (Ziemke et al., 2015). The $\mathrm{O}_{3}$ sensitivity to ENSO was also studied with the tropospheric emission spectrometer (TES) observations (Neu et al., 2014). They studied, during El Niño, the long-range transport of Asian pollution due to the Northern Hemisphere subtropical jet. MLS and TES data were also compared to a chemistry-climate model to study how ENSO can influence the $\mathrm{O}_{3}$ distribution (Oman et al., 2013). These studies demonstrate that the link between $\mathrm{O}_{3}$ and ENSO becomes a key element of the chemistry-climate interactions.

The combination of OMI and MLS measurements allows insights into the links between tropospheric $\mathrm{O}_{3}$ and ENSO, but has limitations because the tropospheric partial $\mathrm{O}_{3}$ columns are obtained as a difference between two large quantities, the total column and the stratospheric column. Hence, possible bias and errors in MLS and OMI data can be amplified when the partial tropospheric column is calculated. The objective of the present study is to obtain direct evaluations of tropospheric ozone using assimilation of ozone profiles from MLS and from IASI.

The IASI instrument, launched onboard MetOp-A in 2006, was designed for numerical weather predictions and atmospheric composition observations (Clerbaux et al., 2009). IASI allows a daily global coverage at very high spatial resolution (12 km for nadir observations). Because of its spatial coverage, the day and night retrieval coverage, IASI provides an important added value with respect to other satellites like TES or OMI (Herbin et al., 2009; Pittman et al., 2009; Oetjen et al., 2016). The IASI mission is meant to last for several decades (MetOp) whereas the instruments OMI, MLS and TES are scientific missions with limited lifespan. Tropospheric $\mathrm{O}_{3}$ from IASI has been already studied and validated. The IASI ozone data were found to be particularly well suited to the study of $\mathrm{O}_{3}$ variations in the upper troposphere (Dufour et al., 2012; Tocquer et al., 2015; Barret et al., 2016). Since we already have about 10 years of data, the IASI mission provides a valuable dataset to study the $\mathrm{O}_{3}$ variability and trends (Toihir et al., 2015; Wespes et al., 2016), both in the troposphere and the stratosphere (Wespes et al., 2009, 2012; Dufour et al., 2010; Barret et al., 2011; Scannell et al., 2012; Safieddine et al., 2013). More recently, the tropospheric $\mathrm{O}_{3}$ variability due to ENSO has been studied using 8 years (January 2008 to March 2016) of IASI measurements (Wespes et al., 2017). They have shown that IASI retrievals can capture the variability of tropospheric ozone related to the large-scale dynamical modes of ENSO.

By assimilating IASI data within the MOCAGE model (Teyssèdre et al., 2007), we expect to obtain $\mathrm{O}_{3}$ distributions consistent with OMI-MLS observations and to have additional information on the vertical $\mathrm{O}_{3}$ distributions in the troposphere. We use the MOCAGE chemistry transport model (CTM) to assimilate tropospheric ozone profiles from IASI and stratospheric profiles from MLS with a 4D-Var (4dimensional-variational) algorithm. The joint assimilation of IASI and MLS data was already found to improve modeled $\mathrm{O}_{3}$ in the UTLS (Barré et al., 2013; Emili et al., 2014). Since the information in IASI retrievals is strongly weighted in the troposphere, the assimilation of MLS allows the introduction of complementary information in the case of stratospheretroposphere exchanges (Barré et al., 2012), which intensify over the eastern Pacific Ocean during the La Niña phase of the ENSO. We will evaluate in this study the relative importance of assimilating MLS and IASI in the context of the $\mathrm{O}_{3}$ variability related to ENSO. To compute ozone tendencies MOCAGE uses the latest version of the linear ozone chemistry parametrization of Cariolle and Teyssedre (CARIOLLE Scheme, 2007).

The influence of ENSO on tropical tropospheric $\mathrm{O}_{3}$ has been simulated by CTMs or by global chemistry-climate models (Sudo and Takahashi, 2001a; Zeng and Pyle, 2005; Doherty et al., 2006; Oman et al., 2011). Fewer studies used data assimilation to study the distribution and interannual variability of tropospheric ozone in the Pacific (Liu et al., 2017; Olsen et al., 2016). Data assimilation allows time series of chemical fields that integrate all available information from measurements and models to be obtained. This can be particularly useful when tropospheric retrievals from satellite measurements become very sparse, due for instance to the occurrence of convective clouds in the tropical region. Furthermore, the assimilation of IASI data for a long time period has not yet been considered. The 6-year reanalysis (2008-2013) of tropospheric $\mathrm{O}_{3}$ that we have computed in the present study is ideal for studying the ozone variability in the tropics from short-term to interannual timescales.

The format of this paper is as follows. In Sect. 2 we describe the observations used for assimilation and model validation, as well as the settings used by the MOCAGE model and the assimilation suite. In Sect. 3 we discuss the results obtained assimilating IASI and MLS data, with an emphasis on the impact of ENSO on tropospheric $\mathrm{O}_{3}$. We derive an Ozone ENSO Index and compare its evolution to previous studies. The final section summarizes the results.

\section{Methodology}

\subsection{Assimilated observations}

\subsubsection{IASI and MetOp-A measurements}

The IASI is one of the instruments onboard the polar-orbiting satellite MetOp-A (Meteorological Operational), which is operated by the European organization for the exploitation of Meteorological Satellites (EUMETSAT). The MetOp-A 
satellite was launched on 19 October 2006 and has already provided data for about 10 years. Due to its inclination to the equatorial plane and its altitude $(817 \mathrm{~km})$, MetOp-A crosses the equatorial plane at 09:30 and 21:30 LT (the equatorial plane at 9:30 and 21:30 local solar time when crossing the Equator).

IASI is a nadir-viewing Fourier Transform Spectrometer. The detectors sense in the thermal infrared spectral range between 645 and $2760 \mathrm{~cm}^{-1}$ (15.5 to $3.62 \mu \mathrm{m}$ ). IASI provides spectra with a high radiometric quality at a resolution of $0.5 \mathrm{~cm}^{-1}$ (after apodization). IASI measurements are taken along- and across-track over a swath width of $2200 \mathrm{~km}$ with an horizontal resolution of $12 \mathrm{~km}$. Therefore, IASI provides global coverage twice a day. The high spectral resolution of IASI allows the retrieval of vertical profiles of a number of gases affecting the climate system and the atmospheric pollution (Clerbaux et al., 2009; Coheur et al., 2009). Previous studies have used vertical information from IASI Level 2 products to study $\mathrm{O}_{3}$ in the troposphere, in the upper troposphere-lower stratosphere (UTLS) and in the stratosphere (Dufour et al., 2010; Barret et al., 2011, 2016; Wespes et al., 2012; Tocquer et al., 2015).

A radiative transfer code and retrieval software are used to retrieve $\mathrm{O}_{3}$ profiles from IASI radiances. We use $\mathrm{O}_{3}$ retrievals performed with the Software for Fast Retrieval of IASI Data (Barret et al., 2011) developed at Laboratoire of Aerology. The SOFRID (SOftware for a Fast Retrieval of IASI Data) is based on the RTTOV (Radiative Transfer for TOVS, Saunders et al., 1999a, b) fast radiative transfer model coupled to the 1D-Var algorithm developed at UKMO (United Kingdom Met Office, Pavelin et al., 2008). SOFRID retrieves the $\mathrm{O}_{3}$ profiles on 43 levels from 1013.25 to $0.1 \mathrm{hPa}$ using a single a priori profile and covariance matrix based on 1 year of in situ observations (see Barret et al., 2011 for details). Validation of 6 months of tropospheric $\mathrm{O}_{3}$ columns from IASI-SOFRID against ozonesondes and airborne data have shown biases of about $5 \%$ and relative standard deviation (RSD) of about $15 \%$ in the tropics. In their validation study of three IASI $\mathrm{O}_{3}$ products over 1 year, Dufour et al. (2012) also found biases of 3.8 and RSD of $9.5 \%$ for IASISOFRID tropospheric $\mathrm{O}_{3}$ relative to ozonesonde data in the tropics. In this study, partial $\mathrm{O}_{3}$ columns between 1013.25 and $345 \mathrm{hPa}$ has been computed from the IASI-SOFRID profile prior to the assimilation.

\subsubsection{MLS measurements}

The MLS instrument flies onboard the Aura satellite in a polar orbit with a continuous record that begins in July 2004. The Aura spacecraft has an equatorial crossing time of 13:45 (local solar equatorial crossing time of 13:45) (ascending node) with approximately 15 orbits per day on average. The MLS measures thermal emissions at the atmospheric limb and provides vertical profiles of several atmospheric constituents (Waters et al., 2006). MLS allows the retrieval of about 3500 profiles per day with a nearly global spatial coverage between $82^{\circ} \mathrm{S}$ and $82^{\circ} \mathrm{N}$. Each profile is spaced by about $165 \mathrm{~km}$ along the orbit track. The recommended useful pressure range (Livesey et al., 2011) for the MLS measurements of the versions $\mathrm{v} 3$ and $\mathrm{v} 4$ is from 261 to $0.02 \mathrm{hPa}$, with a vertical resolution between 2.5 and $6 \mathrm{~km}$, depending on altitude.

For this study we used version 4.2 of the MLS ozone product (Schwartz et al., 2015). Notable improvements of the $\mathrm{v} 4.2$, compared to the earlier versions v3.3 and v3.4, show a reduction in the severity and frequency of cloud impacts on ozone determination. For more information, users of MLS Aura L2 v4.2 should refer to the EOS MLS Level 2 Version 4 Quality Document by Livesey et al. (2016). MLS ozone profiles show good quality in the UTLS, with a precision of about $5 \%$. Biases for MLS ozone profiles are about $2 \%$ in the stratosphere but they increase in the upper troposphere and can be as high as $20 \%$ at the $215 \mathrm{hPa}$ level (Froidevaux et al., 2008). To avoid the introduction of biases at this level in our analyses we have taken the MLS ozone data only between 12.12 and $177.83 \mathrm{hPa}$.

\subsection{Validation measurements}

\subsubsection{The OMI-MLS residual method and the Ozone ENSO Index}

The OMI instrument, is one among a total of four instruments onboard the Aura satellite. It is a nadir-viewing imaging spectrometer that measures the solar radiation reflected by Earth's atmosphere and surface (Levelt et al., 2006). It makes spectral measurements in the ultraviolet (270-314 and $306-380 \mathrm{~nm}$ ) and visible $350-500 \mathrm{~nm}$ wavelength regions at $0.5 \mathrm{~nm}$ resolution. OMI provides measurements with a daily global coverage and a very high horizontal spatial resolution of $13 \mathrm{~km} \times 24 \mathrm{~km}$ at nadir (Dobber et al., 2006). Retrieval errors of the OMI data vary from 6 to $35 \%$ in the troposphere (Liu et al., 2010). Total column ozone from OMI have been derived using the TOMS version 8 algorithm (Ziemke et al., 2006).

To derive TCO with the OMI-MLS residual method, Ziemke et al. (2006) subtracted the stratospheric ozone columns retrieved with MLS from the OMI total column. They selected OMI pixels with near clear-sky conditions (radiative cloud fraction $<30 \%$ ). Stratospheric MLS data were spatially interpolated each day on a coarser regular grid. The tropopause height used for the TCO cutoff between OMI and MLS comes from the National Centers for Environmental Prediction (NCEP) using the $2 \mathrm{~K} \mathrm{~km}^{-1}$ lapse rate tropopause definition (Craig, 1965) of the World Meteorological Organization (WMO). We used OMI-MLS data from the NASA GODDARD website for tropospheric ozone (http://acd-ext. gsfc.nasa.gov/Data_services/). All available daily data have been averaged to compute monthly means with a latitudelongitude resolution of $1^{\circ} \times 1.25^{\circ}$. 
There is no single universal ENSO index reproducing oceanic and atmospheric physical conditions over the tropical Pacific (Trenberth, 1997). Many ENSO indices have been developed using for instance SST and precipitation (Trenberth, 1997; Curtis and Adler, 2000). The commonly used NOAA Niño 3.4 index is derived from SST anomalies. Based on 30 years of satellite measurements to investigate ENSO's impact on tropical TCO, Ziemke et al. (2010) produced a monthly OEI. Stratospheric column ozone in the tropical Pacific has very small longitudinal variations of only a few Dobson units. This has been shown in the previous studies from SAGE, UARS HALOE, UARS MLS and AURA MLS stratospheric $\mathrm{O}_{3}$ satellite measurements (Ziemke et al., $1998,2010)$. Because of this characteristic, the zonal variation of the TCO in the tropical Pacific is essentially identical to the east-west variation of total column ozone. Thus TCO alone can be used to derive the OEI. The OEI is obtained by subtracting the TCO in the region named Pacific Ocean Center (POC, $15^{\circ} \mathrm{S}-15^{\circ} \mathrm{N}, 110-180^{\circ} \mathrm{W}$ ) from the $\mathrm{TCO}$ in the region Indonesia with Indian Ocean (IIO, $15^{\circ} \mathrm{S}-$ $15^{\circ} \mathrm{N}, 70-140^{\circ} \mathrm{E}$ ) each month. To compute the TCO, the altitude of the tropopause must be known. Ziemke et al. (2010) used tropopause heights derived from the NCEP data. The tropopause is defined as the lowest level, with respect to altitude, at which the temperature lapse rate decreases to $2{ }^{\circ} \mathrm{C} \mathrm{km}^{-1}$ or less and does not exceed $2 \mathrm{~K} \mathrm{~km}^{-1}$ for $2 \mathrm{~km}$ above. We adopted this tropopause computation to derive the OEI from our analyses. Tropopause pressures, used to compute the Ozone Index with the assimilation of both IASIMLS and MLS data only, are comprised between $80 \mathrm{hPa}$ at low latitudes and $500 \mathrm{hPa}$ at high latitudes.

\subsubsection{Ozonesondes}

Ozonesondes are launched in many locations over the world on a weekly basis, measuring vertical profiles of $\mathrm{O}_{3}$ concentration with a high vertical resolution of $150-200 \mathrm{~m}$, from the ground to approximately $10 \mathrm{hPa}$. Data are collected by the World Ozone and Ultraviolet Radiation Data Center (WOUDC, http://www.woudc.org). During the 6 years considered in this study (2008 to 2013), only 270 ozone soundings are available for the Pacific area between $15^{\circ} \mathrm{S}-15^{\circ} \mathrm{N}$ and $70^{\circ} \mathrm{E}-110^{\circ} \mathrm{W}$ (Fig. 2). We divide this area into two regions: IIO and POC, which are represented by the two blue rectangles in Fig. 2.

WOUDC ozonesonde measurements used for the validation are considered as a reference. Despite their sparse geographical distribution, several studies have used the WOUDC database to validate global models and satellite retrievals (Geer et al., 2006; Massart et al., 2009; Dufour et al., 2012).

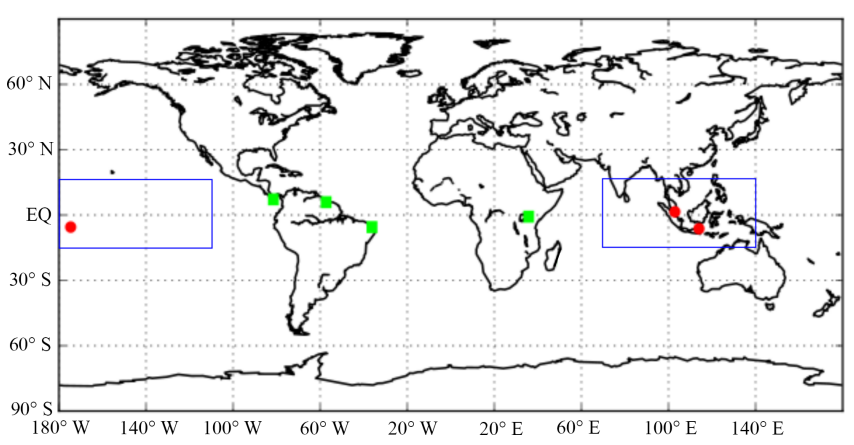

Figure 2. Map of WOUDC ozonesonde localization between $15^{\circ} \mathrm{S}$ and $15^{\circ} \mathrm{N}$. The red circles mark ozonesonde stations between $70^{\circ} \mathrm{E}$ and $110^{\circ} \mathrm{W}$. Green squares are ozonesonde stations elsewhere in the tropical band used hereafter. The two blue squares define the IIO region $\left(15^{\circ} \mathrm{S}-15^{\circ} \mathrm{N}\right.$ and $\left.70-140^{\circ} \mathrm{E}\right)$ and the POC region $\left(15^{\circ} \mathrm{S}-\right.$ $15^{\circ} \mathrm{N}$ and $180-110^{\circ} \mathrm{W}$ ) referred to in this study.

\subsection{Analyses}

\subsubsection{Chemical transport model}

MOCAGE is a three-dimensional CTM based on a semiLagrangian advection scheme (Williamson and Rasch, 1989) developed for both tropospheric and stratospheric applications. Multiple nested domains with different horizontal resolutions can be used within MOCAGE, as well as chemical and physical parameterizations of increasing complexity. The different configurations of MOCAGE have been validated against in situ, satellite and ground-based measurements in several studies (Josse et al., 2004; Teyssèdre et al., 2007; Bousserez et al., 2007; Honoré et al., 2008; Sič et al., 2015). For this study, a global horizontal resolution of $2^{\circ} \times 2^{\circ}$ has been used with 60 sigma hybrid vertical levels from the surface up to $0.1 \mathrm{hPa}$. The vertical resolution goes from about $40 \mathrm{~m}$ in the boundary layer, to about $500 \mathrm{~m}$ in the free troposphere and to approximately $800 \mathrm{~m}$ in the upper troposphere and lower stratosphere. The model uses winds, temperature and ground pressure from the European Center for Medium-Range Weather Forecasts (ECMWF) ERA-Interim reanalysis (Berrisford et al., 2011).

For the chemical scheme we use the simplified ozone chemistry scheme developed by Cariolle and Teyssedre (2007), based on the linearization of the destruction and production rates of ozone. Emili et al. (2014) have shown that with this simplified chemical scheme it is possible to obtain $\mathrm{O}_{3}$ analyses from IASI data of comparable quality to those obtained using more complex chemical schemes. The use of this simplified scheme reduces numerical costs, which is highly beneficial for the production of long chemical reanalyses such as the ones discussed in this study. Since the linearized chemistry scheme does not have any longitudinal variation, the longitudinal ozone variability that is reproduced by the model (e.g., in correspondence of the Walker 
circulation, see Sect. 3.2.1) results only from the ozone transport.

\subsubsection{Assimilation algorithm}

The chemical data assimilation system for MOCAGE is developed at CERFACS and has already been used for several applications at both regional and global scales (El Amraoui et al., 2010; Sič et al., 2016). The MOCAGE assimilation system was part of the first international exercise of satellite ozone assimilation (Geer et al., 2006) and it currently provides operational air quality analyses for the european project CAMS (Marécal et al., 2015). The assimilation configuration used for this study is based on the 4DVar algorithm in a "perfect model" framework. Compared to the 3D-Var algorithm, the 4D-Var allows a better exploitation of satellite observations with large spatial and temporal fingerprint (Massart et al., 2010). The cost function is minimized using the limited-memory BFGS (Broyden-FletcherGoldfarb-Shanno) method (Liu and Nocedal, 1989) and the three-dimensional background error covariance matrix $(\mathbf{B})$ is modeled through a diffusion equation (Weaver and Courtier, 2001).

The IASI partial $\mathrm{O}_{3}$ columns $(1000-345 \mathrm{hPa})$ and MLS profiles have been assimilated in the troposphere and in the stratosphere respectively to constrain the ozone concentration along the full atmospheric column. For this study, the choice of the assimilated column top $(345 \mathrm{hPa})$ has been taken based on SOFRID averaging kernels found over the tropics (Barret et al., 2011). The objective was to minimize the extent of the atmospheric layer where both MLS and IASI can have a direct impact. This avoids to some extent the need to quantify and account for possible biases between the two instruments. Before the assimilation, IASI data have been averaged to obtain $2^{\circ}$ by $2^{\circ}$ pixels to match the model resolution. The smoothing equation based on the averaging kernels (AKs) and on the a priori profile in the troposphere has been applied to the profiles from the model to account for the limited sensitivity of IASI retrievals in the troposphere (see Barret et al., 2016). The description of the linear retrieval equation can be found in Barret et al. (2011). Emili et al. (2014) found global biases of $10 \%$ in the troposphere-assimilating IASI-SOFRID product in MOCAGE. When they removed $10 \%$ of the values in the IASI observations, the biases in the analyses were significantly reduced. The same correction has been applied in this study.

Most of the parameters of the assimilation algorithm used to compute the reanalyses in this study are based on the study of Emili et al. (2014). The validation of a short reanalysis of 2 months against ozonesondes (not shown) has been used to further optimize some of these parameters. The background and observation errors are defined as follows. Emili et al. (2014) have assimilated IASI and MLS data globally with a background error standard deviation equal to $30 \%$ of the modeled ozone profile in the troposphere and $5 \%$ in the stratosphere. Based on local validation in the tropics, we found slightly superior results using an error standard deviation of 15 instead of $30 \%$ in the troposphere. Therefore, this choice has been taken for the 6-year reanalyses. We specify the background error variances as a percentage of the modeled ozone profile equal to $15 \%$ in the troposphere and $5 \%$ in the stratosphere. These values were established through a global validation of ozone forecasts against ozonesondes. We use horizontal correlation length that differs for meridional and zonal dimensions. The meridional length scale is fixed to a constant value of $300 \mathrm{~km}$ and the zonal length scale varies from $500 \mathrm{~km}$ at the equator to $100 \mathrm{~km}$ at the poles. Further tests led us to deactivate the vertical error correlation, compared to the value of one grid point used in the previous study (Emili et al., 2014). Ozonesonde validation has shown a $20 \%$ decrease in bias close to the tropopause when deactivating the vertical correlation, the scores remaining the same elsewhere. The reason for such improvement is due to the relatively coarse vertical resolution of the model compared to the magnitude of the ozone gradient at the tropopause. When a nonzero error correlation is used, large assimilation increments due to the lowermost MLS observations can spread into the upper troposphere and degrade the ozone concentration. For IASI data we set the variance of the observation error equal to $15 \%$ of the measured ozone columns. The error covariance matrix of the MLS retrieval is prescribed from retrieval product of MLS measurements.

\section{Results}

We have performed three ozone simulations covering the period 2008 to 2013. The first simulation, called Direct Model (DM), has been produced by running the MOCAGE CTM without data assimilation. The model is initialized with a climatology on 1 November 2007 to allow for a spin-up period of 2 months. The second simulation, named MLS-a, started in January 2008 with the assimilation of MLS profiles for the whole period. Finally, the third simulation (IASI-a) was produced with the assimilation of IASI tropospheric $\mathrm{O}_{3}$ columns and MLS stratospheric $\mathrm{O}_{3}$ profiles. Both MLS-a and IASI-a are initialized with the direct model output on 1 January 2008. For the three simulations the outputs are recorded every 6 hours.

The main results are outlined as follows. Section 3.1 contains the validation of the simulations against ozonesondes. The first validation (Sect. 3.1.1) has been done considering all the measurements available in the latitude band between $15^{\circ} \mathrm{S}$ and $15^{\circ} \mathrm{N}$, providing a statistically significant validation in the tropical region. The following section (Sect. 3.1.2) limits the comparison with $\mathrm{O}_{3}$ soundings over the region directly influenced by ENSO events. In Sect. 3.2 we analyze the temporal and spatial variability of TCO during the period 2008-2013. The link between sea surface temperature and ozone variability is studied with the OMI-MLS estima- 
tions (see Sect. 2.2). The objective is to evaluate how modeled ozone distributions reproduce the observed ozone variability over the Pacific ocean during the normal conditions of the Walker cell and during ENSO events. In Sect. 3.2.2, we compare the Ozone ENSO Index (OEI), computed using the previous datasets, to the Niño 3.4 index, to demonstrate the added value of IASI tropospheric assimilation for long-term ozone monitoring. Finally, in Sect. 3.2.3 the vertical distributions of ozone are examined over two regions (eastern Asia and Indonesia and over the Pacific Ocean) to highlight the footprint of ENSO within the three model simulations.

\subsection{Validation with ozonesonde measurements}

\subsubsection{The equatorial latitudes}

The $\mathrm{O}_{3}$ data have been treated as follows: (i) the modeled fields have been collocated with the soundings in space and time, and (ii) the obtained values have been averaged on a 2-month basis, in order to take into account a larger number of soundings for statistical evaluations. The collocation was done with a linear interpolation along each dimension, which results in a linear interpolation in time of the model's 6-hourly outputs and trilinear interpolation in space (on both the horizontal and vertical dimensions).

Figure 3 shows the comparison between the partial ozone column of the three simulations and the ozonesonde data in the tropical band $\left(15^{\circ} \mathrm{S}-15^{\circ} \mathrm{N}\right)$. Partial ozone columns (in DU) and relative differences (in \%) are plotted separately for the TCO (1000-100 hPa), the boundary layer (1000$750 \mathrm{hPa})$ and the free troposphere $(750-100 \mathrm{hPa})$. The TCO from ozonesondes (Fig. 3a) has maxima in summer-fall and minima in winter. The observed seasonal variation is a consequence of biomass burning, which provides precursors for ozone formation in summer-fall. The emission of gases by biomass burning, such as carbon monoxide and carbonaceous aerosols, intensifies during the dry season (June-July and August-October) over both the South American and South African regions (Andreae et al., 1998; Sinha et al., 2004). The ozone columns produced by the DM and MLSa simulations do not show the variability measured by the ozonesondes; their correlation coefficients with the sondes data are lower than 0.76 (Fig. 3a, b). The IASI-a variability matches the ozonesondes better with a correlation coefficient of 0.88 . In particular the IASI-a simulation exhibits a yearto-year variability that agrees very well with the ozonesonde data. This is confirmed by the RSD of the differences between simulated and observed values: the RSD of IASI-a is $6 \%$ whereas it is about $10 \%$ for MLS-a and MD. The relative differences between simulated and observed values are presented in Fig. 3b. IASI-a is less biased (6\%) than DM and MLS-a, and MLS-a has lower biases (24\%) than DM (32\%). Biases are lower with MLS-a, compared to DM, due to the assimilation of MLS stratospheric data. The MLS-a improvement is due to the direct influence of the lowest assimilated level of MLS $(170 \mathrm{hPa})$ which brings information on the $\mathrm{O}_{3}$ distribution in the UTLS region. Compared to IASI-a the lower accuracy of DM comes from the use of the simplified ozone scheme, which does not account for the production of tropospheric ozone by biomass burning.

Figure $3 \mathrm{c}$ and $\mathrm{d}$ show that the IASI-a tropospheric columns are biased high in the lower troposphere. In this region, the RSDs of the three simulations are very similar, implying a similar variability compared to ozonesondes, even if IASIa matches the ozonesondes slightly better. However, IASI-a is half as accurate for the boundary layer $\mathrm{O}_{3}$ column than for the TCO and its biases are higher than MD and MLSa. Larger biases in the boundary layer are a consequence of both the low degrees of freedom of IASI retrievals in the troposphere and the presence of a DM bias with opposite sign between the free troposphere and the boundary layer. The positive correction provided by IASI assimilation in the free troposphere propagates downward in the boundary layer, therefore increasing the original DM bias.

Ozone concentration and biases of the IASI-a simulation in the free troposphere (Fig. 3e and Fig. 3f) show much better results than the two other simulations. As can be seen, the sensitivity of the IASI measurements is larger in the midand upper troposphere. The RSD of IASI-a is around $6 \%$ instead of $11 \%$ for DM and $9 \%$ for MLS-a in the middleupper troposphere (Fig. 3f). The added value of IASI data in the middle troposphere is particularly remarkable in the case of bias, which is $2 \%$ for IASI-a instead of 41 and $32 \%$ for DM and MLS-a, respectively. Since the boundary layer $(1000-750 \mathrm{hPa})$ corresponds approximately to $12 \%$ of the TCO $(1000-100 \mathrm{hPa})$, the overestimation of the ozone column by IASI-a does not have a major impact on the TCO used for our study of the ENSO-O 3 correlation, which is the main objective of this study.

\subsubsection{From eastern Africa to South America: focus on the ENSO}

To study the ENSO we divide the region of interest (latitude ranges from $15^{\circ} \mathrm{S}$ to $15^{\circ} \mathrm{N}$ and longitude ranges from $70^{\circ} \mathrm{E}$ to $110^{\circ} \mathrm{W}$ ) in two areas (see Fig. 2): the first one, called IIO, has a longitude range between 70 and $140^{\circ} \mathrm{E}$ while the second one, called POC, is located between 180 and $110^{\circ} \mathrm{W}$. Three ozonesonde stations are available for both regions, two in the IIO region and one in the POC region (Table 1).

Ozone measurements for each site are available over different time periods. The Malaysia site provides measurements only between January 2008 and December 2009, the Indonesia site from January 2008 to December 2012, and the Samoa site from January 2008 to December 2013. Due to the small number of ozonesonde measurements, results of the statistical validation presented here should be considered with more caution than in the previous section. The main objective of this section is to check whether the reanalysis can capture strong local variations of TCO due to ENSO. 
(a) $\mathrm{O}_{3}$ columns

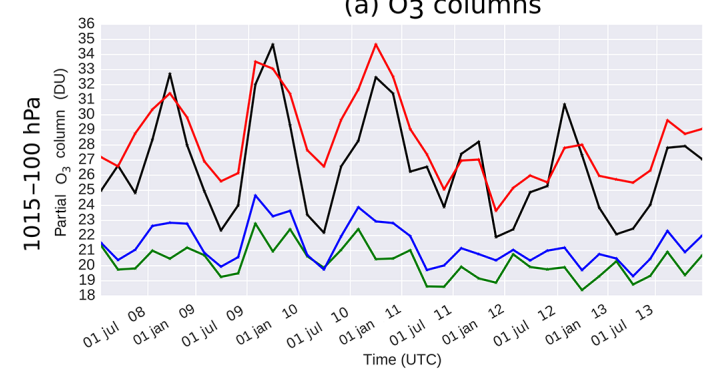

(c) $\mathrm{O}_{3}$ columns

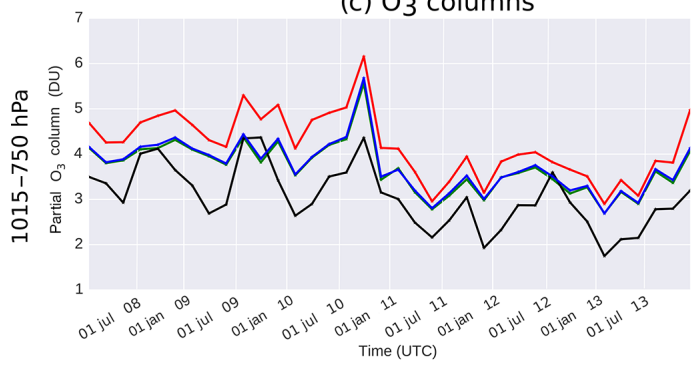

(e) $\mathrm{O}_{3}$ columns

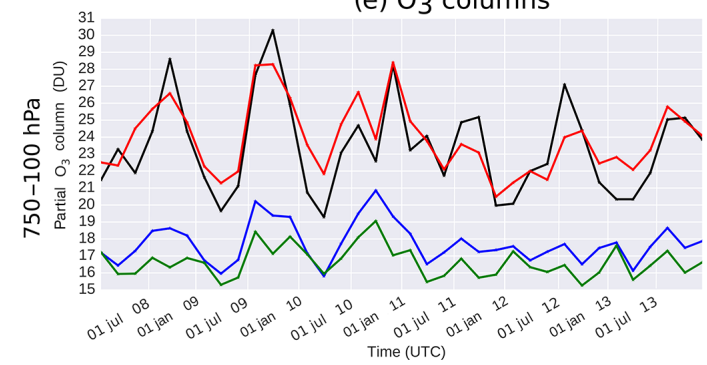

(b) Relative differences

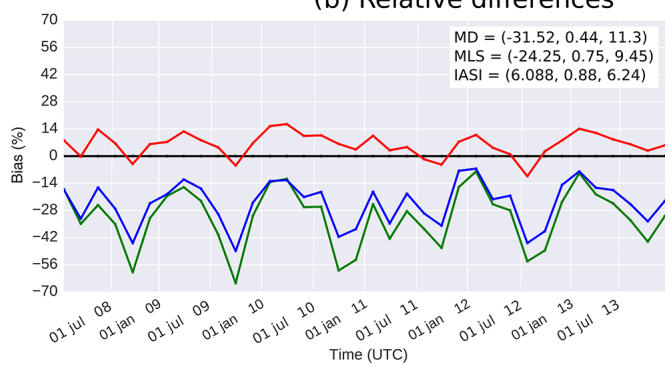

(d) Relative differences

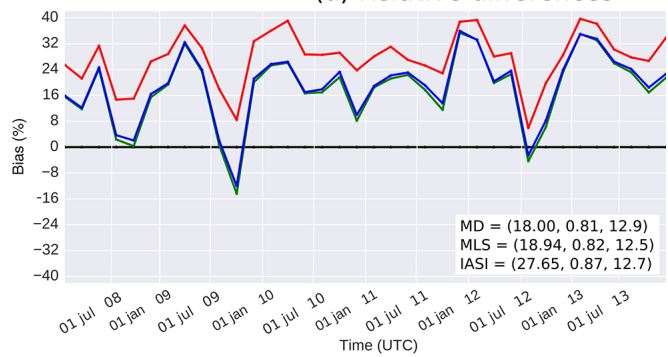

(f) Relative differences

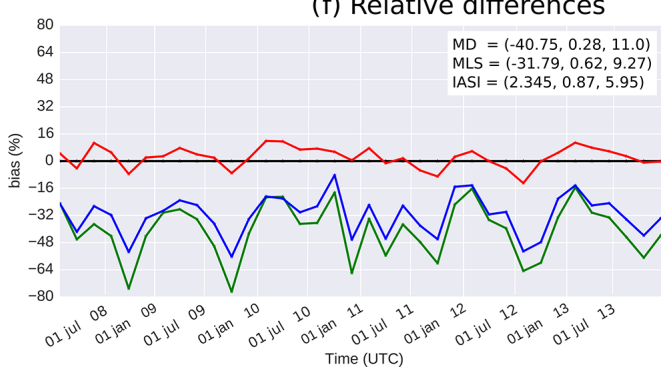

Figure 3. Time series of partial ozone columns (a, c, e, in DU) from the IASI-a (red curves), the MLS-a (blue curve), and the DM (green curve) plotted versus several stations measurements from WOUDC (black curves). Data are 2-month averages over the area $15^{\circ} \mathrm{S}-15^{\circ} \mathrm{N}$ and $180^{\circ} \mathrm{W}-180^{\circ} \mathrm{E}$ for $(\mathbf{a})$, the ozone column between 1015 and $100 \mathrm{hPa}(\mathbf{b})$, the boundary layer $(1015-750 \mathrm{hPa})(\mathbf{c})$, (d) and the free troposphere $(750-100 \mathrm{hPa})(\mathbf{e}),(\mathbf{f})$. Biases in percentages are shown in (a), (c) and (e). Mean biases, correlation coefficients and standard deviations are also given (between brackets in $\mathbf{b}, \mathbf{d}$ and $\mathbf{f}$ ).

Table 1. Ozonesonde stations at tropical latitudes between $70^{\circ} \mathrm{E}$ and $110^{\circ} \mathrm{W}$.

\begin{tabular}{lllr}
\hline Name & Ozonesondes & Localization & Coordinates \\
\hline Malaysia & $443 \mathrm{ECC}$ & Kuala Lumpur international airport, Malaysia & $3^{\circ} \mathrm{N}-101^{\circ} \mathrm{E}$ \\
Indonesia & $437 \mathrm{ECC}$ & Watukosek, Java Timur, Indonesia & $8^{\circ} \mathrm{S}-113^{\circ} \mathrm{E}$ \\
Samoa & $191 \mathrm{ECC}$ & Apia, Samoa & $13^{\circ} \mathrm{S}-172^{\circ} \mathrm{W}$ \\
\hline
\end{tabular}

Figure 4 shows the statistics of the IASI-a $\mathrm{O}_{3}$ simulation versus the three records from the ozone soundings. Time series are computed in the same manner as the time series over the tropical band discussed in the previous section (Sect. 3.1.1). From January 2008 to December 2009, TCOs from the ozonesondes located in the IIO region (Fig. 4a, c) and those located in the POC region (Fig. 4e), has a seasonal variability, with maxima in boreal summer and minima in boreal winter. This ozone seasonality is caused by the biomass combustion over the western Pacific Ocean near New Guinea during the dry period (Kim and Newchurch, 1998). Among the countries of southern Asia, Indonesia is known as the country with the third-highest biomass burning emissions (Streets et al., 2003). During the year 2010 and over the IIO region (Fig. 4c), the variability of ozone concentrations has a different seasonality. We see a peak of ozone during March 2010 over Indonesia (26 DU) whereas there is a minimum in Samoa (12 DU) (Fig. 4e). This ozone rise over the IIO region is linked with subsidence, generated by the El Niño event starting in January 2010 (see Fig. 1). El Niño intensifies the subsidence and therefore dry conditions and biomass burning over southern Asia (Matsueda et al., 2002; Chandra et al., 2002). From September 2010 to August 2011, the TCO values decrease to an average of about 
20 DU over Indonesia. This decrease in tropospheric ozone is due to the other phase of ENSO: La Niña. As we have already mentioned (Fig. 1), La Niña strengthens the convection over the IIO causing a minimum in the TCO. Hence, there is a lower TCO over Indonesia (around 20 DU) than over Samoa (around 28DU). After summer 2011 the ENSO disappears and the TCO returns to normal seasonality.

IASI-a reproduces quite well the variability measured by the ozonesondes during normal conditions of the Walker circulation (2008-2009) and during the ENSO (2010-2011). In particular, IASI-a agreement with the ozonesondes is better over the POC region (Samoa), where the correlation coefficient is 0.96 , than over Indonesia and Malaysia where the coefficients are around 0.7. However, the relative difference between IASI-a and the ozonesondes is larger over the POC region (Fig. 4f) than over the IIO region (Fig. 4b, d), with an overestimation of the ozone columns by about $17 \%$ in Samoa. Mean biases are around 3-5\% for over Indonesia and Malaysia, showing that IASI-a reproduces quite well the ozone variability during normal conditions of the Walker circulation. Equally, IASI-a reproduces the maximum over Indonesia and the minimum over Samoa during the $2010 \mathrm{El}$ Niño event, as well as the TCO minima generated during La Niña over the IIO region. As already discussed, biases observed in the POC and IIO regions come from the decreased sensitivity of IASI in the boundary layer, and from the lack of adequate representation of the chemistry in the lower troposphere by the linear scheme used within MOCAGE. The three simulations (IASI-a, MD and MLS-a) have identical biases in the boundary layer compared to the ozone soundings (figures not shown). Biases in the boundary layer are higher in the POC region (around $45 \%$ ) compared to the IIO region (around $20 \%$ ). However, in the POC region, the variability of the three simulations are remarkably well correlated with the ozonesondes, with coefficient correlations higher than 0.85 (not shown).

To summarize, the IASI-a simulation reproduces well the $\mathrm{O}_{3}$ variability observed with the ozonesondes for the tropical latitudes and for both regions of POC and IIO. The seasonal oscillations of ozone, caused by the anthropogenic pollution and by ENSO, are reproduced by IASI-a despite a slight overestimation of about $4 \%$ in the IIO region and around $17 \%$ in the POC region. The IASI-a simulation is thus adequate to study ozone variability during ENSO events since biases are not very large over the period under study.

\subsection{Temporal and spatial variability of ozone during ENSO}

\subsubsection{Characterization of ENSO and footprints on SST and tropospheric ozone content}

In this section we consider the link between SST and tropospheric ozone during ENSO events. Previous studies have highlighted the link between SST anomalies and ENSO dy- namics (Philander, 1989; Barnston et al., 1997; Wang et al., 2014). Colder SST in the POC region is associated with $\mathrm{La}$ Niña whereas El Niño has warmer SST than under normal conditions (Trenberth, 1997). Variations in TCO concentrations are a combination of biomass burning rejecting large quantities of ozone precursors (Chandra et al., 2002) and an eastward shift in the tropical convection of the Walker circulation associated with SST changes (Chandra et al., 1998; Sudo and Takahashi, 2001a). The correlation between SST and TCO have already been characterized using OMI-MLS data; our objective is to see if similar correlations can be derived using the model simulations. To this end, we have taken SST data from the Giovanni Interactive Visualization and Analysis GES DISC: Goddard Earth Sciences, data and Information Services Centre (https://disc.gsfc.nasa.gov). The SST data were measured by the instrument MODIS (Moderate Resolution Imaging Spectroradiometer) aboard the Aqua satellites (NASA Earth Observing System platforms).

Figure 5 shows the time versus longitude Hovmöller diagram, averaged between $15^{\circ} \mathrm{S}$ and $15^{\circ} \mathrm{N}$, of the monthly mean SST and the OMI-MLS measurements. SST over the Pacific ocean has a characteristic geographic distribution (Fig. 5a), with the warmest water in the IIO region $(70$ $\left.140^{\circ} \mathrm{E}\right)$ and coldest water in the POC region $\left(180-110^{\circ} \mathrm{W}\right)$. The link between SST and TCO (Chandra et al., 1998, 2009) is observed comparing the SST (Fig. 5a) with OMI-MLS measurements (Fig. 5b). The warmest water-induced convective movements result in a TCO decrease and vice versa for the coldest water. During El Niño (January 2010) the warm SST shifts from the IIO region to the POC region. These eastward shifts in SST coincide with eastward shifts of TCO from July 2008 to January 2010. During La Niña (occurred between September 2010 and January 2011) an opposite condition occurs with the strengthening of colder SST between 80 and $150^{\circ} \mathrm{W}$. In this region of colder SST (Fig. 5a), higher TCO (26-32 DU) is located between the coast of South America and $140^{\circ} \mathrm{W}$ (Fig. 5b). The eastward shift of SST occurring from January 2011 to December 2013 corresponds to the return of normal conditions over the $\mathrm{Pa}$ cific ocean and impacts TCO with an eastward shift.

To compare the three model simulations, with OMI-MLS, we have computed anomalies of tropospheric ozone of each dataset for the period 2008-2013 (Fig. 6). The anomalies are calculated by subtracting the time-averaged TCO to each TCO determination and this difference has been divided by the mean TCO. The TCO anomalies are expressed in percentage. The variability of TCO, observed previously with OMI-MLS measurements in Fig. 5, is also clearly visible with the TCO anomaly (Fig. 6a). The TCO with values $20 \%$ lower than average are located in the IIO region. The TCO with values $20 \%$ higher than average are located close to South American coasts. The El Niño event on January 2010 has a significant impact on TCO, with $20 \%$ higher values in the IIO region and $10 \%$ lower in the POC region. The $\mathrm{La}$ Niña event that follows shows different localization on the 

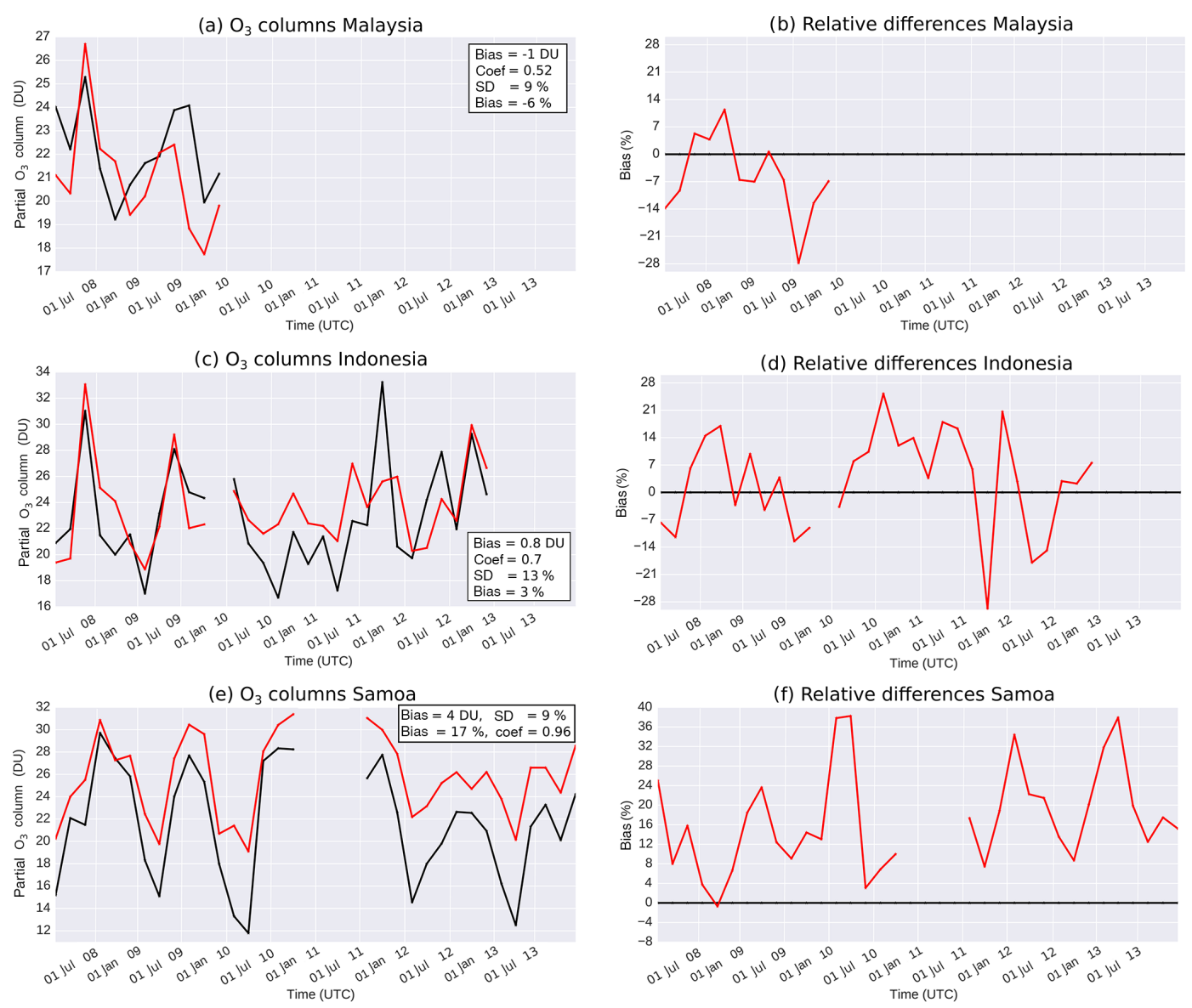

Figure 4. Comparisons between IASI-a (in red) and ozonesondes (in black). Time series of the TCO (in DU) are plotted on the left and relative differences are on the right for the sites of $(\mathbf{a}, \mathbf{b})$ Malaysia, $(\mathbf{c}, \mathbf{d})$ Indonesia and (e), (f) Samoa.

TCO maximum with a maximum between 110 and $80^{\circ} \mathrm{W}$. Part of the TCO variability in the eastern and western Pacific Ocean linked with the Walker circulation is reproduced with the DM simulation (Fig. 6b). The TCO with values $10 \%$ higher (10\% lower) than average are located in POC (IIO) region. However, the amplitude of the TCO anomalies from the DM simulation is much lower compared to OMI-MLS. Since the chemical scheme used in the MOCAGE model has no longitudinal forcing in the chemical tendencies, the TCO anomalies in the DM simulation are only due to changes in the equatorial circulation and the associated ozone transport. The ECMWF analyses capture the dynamics associated with the Walker circulation and to ENSO and hence drive the variations of the TCO seen in the DM simulation. The assimilation of MLS $\mathrm{O}_{3}$ profiles in the stratosphere does not change the structures and percentages of anomalies of the TCO much, and the results of the MLS-a simulation (Fig. 6c) are similar to those of the DM. The eastward shift during El Niño and higher TCO in the POC region during La Niña are represented with both simulations but the TCO anomalies for both simulations are $10 \%$ lower than with those of OMIMLS. Basically the ENSO impacts the troposphere and little information is brought by the assimilation of MLS data. The eastward shift during El Niño and higher TCO in the POC region during La Niña are underestimated by both simulations. Compared to DM and MLS-a the TCO variability is much better reproduced with IASI-a (Fig. 6d). The amplitude of the TCO changes caused by El Niño and La Niña compares very well with the OMI-MLS observations. However, small differences appear between IASI-a and OMI-MLS. Over the IIO region during El Niño the TCO anomaly is $10 \%$ lower with IASI-a than with OMI-MLS. In addition, the location of the TCO maximum during La Niña is located in the whole POC region with IASI-a and in the eastern part of the POC region with OMI-MLS.

Overall, the anomalies of the TCO reproduced by IASIa are in good agreement with those of OMI-MLS. The improvement compared to the DM and MLS-a simulations is very significant, thus demonstrating the usefulness of the IASI data for the ozone evaluation in the troposphere. Equally, the assimilation process is efficient to follow ozone variability and the resulting IASI-a analysis appears to give a consistent dataset for the study of the ozone variability. The advantage of IASI-a over OMI-MLS is that the analyses are 
fully four-dimensional with 6-hourly outputs and resolved information on the vertical dimension. The vertical distributions are studied in Sect. 3.2.3.

\subsubsection{Intercomparison of Ozone ENSO Indices}

The OEI is the TCO difference computed between the IIO region $\left(70-140^{\circ} \mathrm{E}\right)$ and the $\mathrm{POC}$ region $\left(180-110^{\circ} \mathrm{W}\right)$. The resulting time series are then deseasonalized. This deseasonalization is done to remove the signal of the annual cycle (Ziemke et al., 2010). OEI is a strong indicator of the ENSO intensity influencing the tropospheric ozone over IIO and POC regions (Ziemke et al., 2010). It is considered as a basic diagnostic tool to evaluate the ability of the models to reproduce changes in tropospheric ozone linked with ENSO (Ziemke et al., 2010, 2014).

Figure 7 shows the OEI during the period January 2008 to December 2013 computed from our model analyses and from the OMI-MLS data. The OEI variations are related to ENSO, with maxima during El Niño and minima during La Niña events. In Fig. 7a we have plotted the OEI computed for the OMI-MLS measurements (noted OMI-MLS) and the Niño 3.4 index. The monthly Niño 3.4 is calculated from SST anomalies in the Pacific Ocean. The Niño 3.4 index calculated from SST is available from the NOAA website (http:// www.cpc.ncep.noaa.gov/data/indices/). Sea surface temperature anomalies were calculated using the monthly Extended Reconstructed Sea Surface Temperature version 4 (ERSST.v4, 1950-2016 base period). Also included is the OEI of OMI-MLS smoothed using a 3-month running average, as computed by Ziemke et al. $(2010,2014)$ and called OEI-Z hereafter. Figure $7 \mathrm{~b}$ shows the OEI computed from IASI-a, MLS-a, DM and OMI-MLS. Our OEI indices from OMI-MLS, DM, MLS-a and IASI-a are computed without time averaging, by subtraction of TCO in the POC region from TCO averaged over the IIO region. As defined by the NOAA, the two ENSO phases occur when the Niño 3.4 index is higher than 0.5 (corresponding to El Niño) and lower than -0.5 (corresponding to La Niña) during five consecutive months. Thus, in the analyzed period an El Niño starts on July 2008 with a maximum on January 2010, and a La Niña starts on July 2010 with a maximum on January 2011. The two time series of OEI-Z and OMI-MLS appear remarkably similar (Fig. 7a), except around January 2008. For this period they are out of phase with the Niño 3.4. The discrepancy is attributed to the phase opposition between the interannual and intraseasonal variability of the TCO (Ziemke et al., 2014) linked with the intraseasonal Madden-Julian Oscillation (MJO, Madden and Julian, 1972, 1994). The MJO increases the differences between OEI-Z and OMI-MLS in 2008. Detailing the effect of MJO on monthly OEI is beyond the scope of our current study. As expected, the OEI from OMI-MLS shows a consistent variability with OEI-Z; in particular the maxima and minima agree and are well correlated to the Niño 3.4 index. Since the OMI-MLS OEI is obtained from monthly averages it exhibits shorter term variability than OEI-Z and can be directly compared to the indices derived from the model simulations.

The DM OEI (Fig. 7b, green curve) is negative during the whole period, corresponding to a tropospheric column higher over the POC region than over the IIO region. The DM OEI variations show some features of the ENSO, with a relative maximum in January 2010 followed by a minimum at the end of the same year, but the intensity is weak: about 3 times lower than values observed with OMI-MLS. The MLS-a produces an OEI very similar to DM. As already discussed, constraining the ozone profile in the stratosphere has little impact on the quality of the modeled ENSO $\mathrm{O}_{3}$ signal. With the IASI-a we can quantify the contribution of IASI data in the computed OEI (Fig. 7b, red curve). Compared to DM and MLS-a simulations the IASI-a analysis produces OEI in better agreement with the ones derived from OMI-MLS. The OEI variations are in phase with a very good match of periods of maxima and minima. There is, however, a constant bias of approximately 2.4 DU between the indices of OMIMLS and IASI-a. As discussed in Sect. 3.1.2, IASI-a bias in the lower troposphere is larger in the POC region than in the IIO region. This difference of biases between POC and IIO regions affects the determination of the OEI. In addition, during ENSO events we have seen from the Hovmöller plots in Sect. 3.2.1 that during La Niña the TCO maximum with IASI-a is slightly shifted to the western part of the POC region compared to the OMI-MLS data. The difference in the location of maxima over the eastern Pacific between OMIMLS and IASI-a explains part of the difference in the OEI absolute values during El Niño and La Niña events (Fig. 7).

Tropospheric ozone variability during ENSO is therefore very well captured from the OEI variations computed from IASI-a, despite a constant bias in the boundary layer. Further insights into the vertical distribution of $\mathrm{O}_{3}$ over the $\mathrm{POC}$ and $\mathrm{IIO}$ regions during ENSO are discussed in the next section.

\subsubsection{Vertical structure of $\mathrm{O}_{3}$}

The evaluations of TCO obtained with the OMI-MLS by subtracting stratospheric ozone from MLS from the total ozone from OMI cannot give information on the vertical structure of the $\mathrm{O}_{3}$ anomalies forced by ENSO. This is clearly an advantage of model assimilations that can give a complete three-dimensional structure of the ozone fields with no gaps due to orbitography and clouds. We focus here on the information brought by the assimilation of IASI and MLS data in describing the vertical ozone response to ENSO in the POC and IIO regions. Figure 8 shows monthly mean ozone profiles for IASI-a, MLS-a and DM, over the 6-year record. The tropopause pressure for the three simulations is about $100 \mathrm{hPa}$. Ozone concentration in this layer is around $70 \mathrm{ppbv}$. Due to the limitations of the model and the lack of information brought by the two instruments in the boundary layer, as 
(a) SST measurements

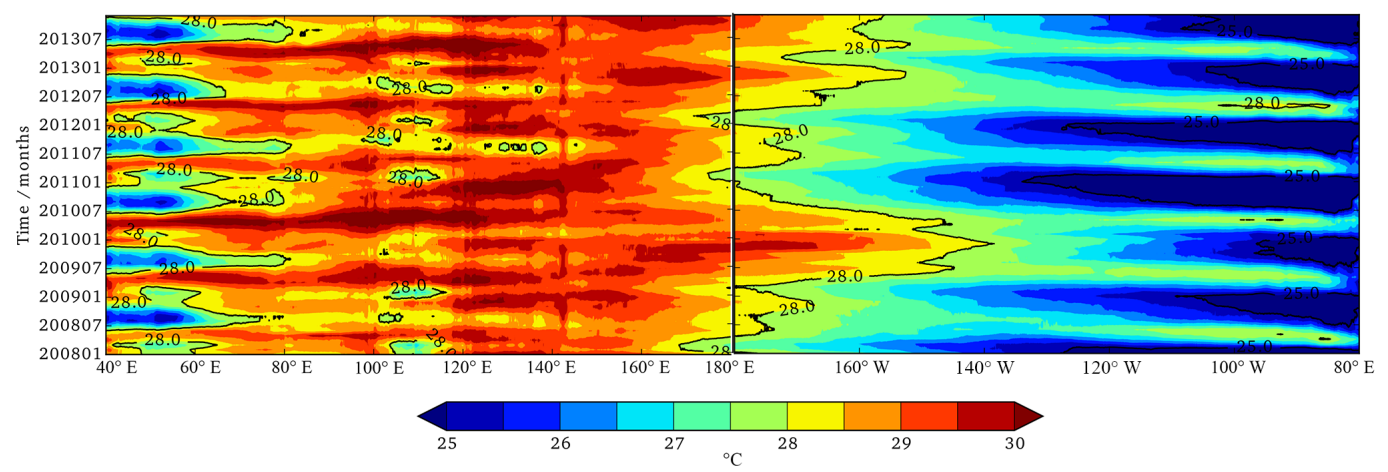

(b) OMI-MLS TCO
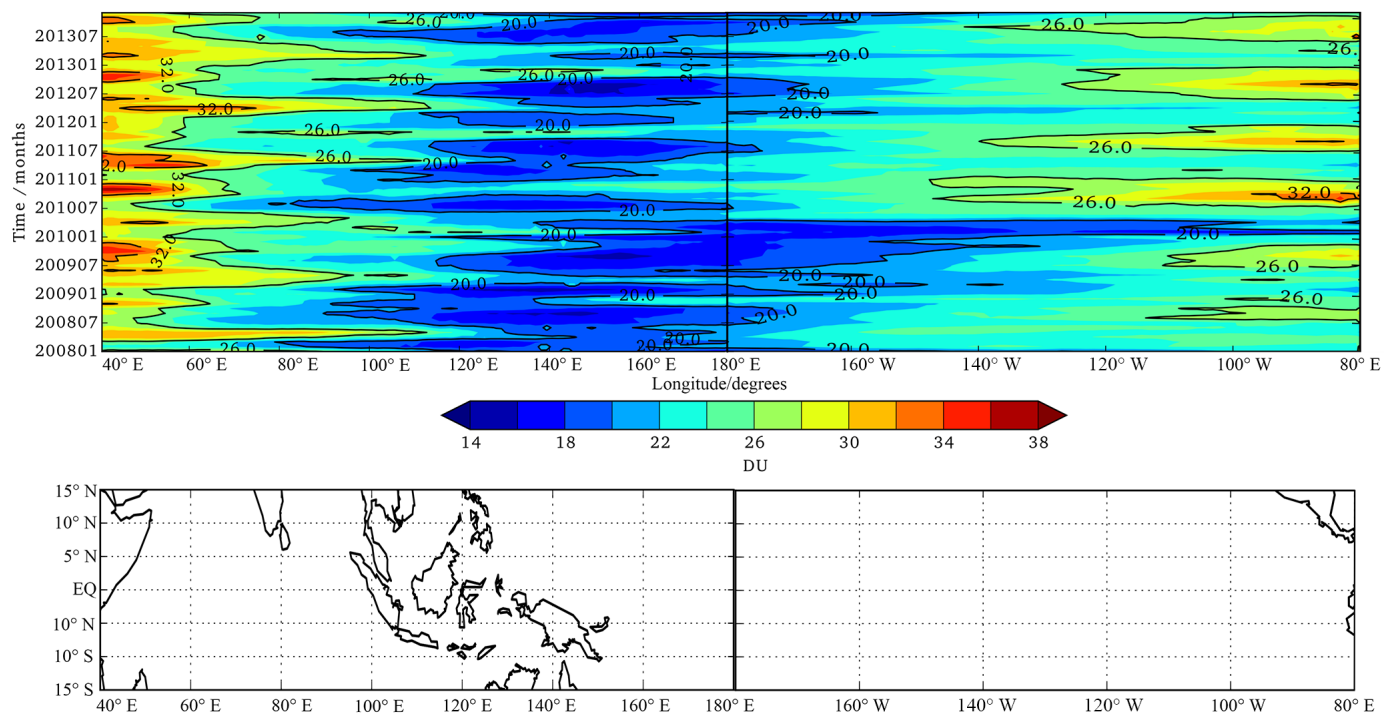

Figure 5. (a) Time versus longitude Hovmöller diagram of the SST (in ${ }^{\circ} \mathrm{C}$ ). (b) Same diagram from the OMI-MLS data. The data are monthly means from January 2008 to December 2013 and area-averaged between latitudes $15^{\circ} \mathrm{S}$ and $15^{\circ} \mathrm{N}$. Also included on the bottom are the corresponding maps of the Hovmöller diagram.

already discussed, we focus our analysis in the IIO et POC regions on the free troposphere, between 750 and $100 \mathrm{hPa}$.

The DM (Fig. 8a, b) and MLS-a (Fig. 8c, d) produce very close distributions of the vertical ozone concentration. The MLS-a simulation shows slightly more ozone in the lower stratosphere and upper troposphere, but the fluctuations of the concentration have similar amplitudes in both simulations. Particularly noticeable is the signal during the 2010 El Niño with low ozone values in the POC region during the first months of the year linked to increased convection and associated upward motions, and an opposite behavior in the IIO region with subsidence and increased ozone down to the middle troposphere. This footprint of ENSO is very well captured with the IASI-a simulation, especially over the POC region. Over that region the ozone content is lower than 35 ppbv during El Niño and larger than 50 ppbv during La Niña. The information brought by IASI is very significant, the amplitude of the ozone change between El Niño and La
Niña periods is 2 to 3 times larger with IASI-a assimilation than it is with DM and MLS-a simulations. If we refer to OEI indices (Fig. 7) some ENSO activity is detected in late 2012early 2013. Indeed an $\mathrm{O}_{3}$ minimum in early 2013 followed by a maximum in the middle of the year is clearly visible in the IASI-a assimilation in the POC region. The amplitude of the ENSO signal on ozone is lower than for the 2010 event, in agreement with the lower values of the Niño 3.4 index. Also more clearly visible with IASI-a are the seasonal variations of the ozone content in the IIO region that is quite regular outside ENSO periods. In that region the annual periodicity of ozone is much pronounced in comparison to the more erratic variations shown in the POC region. The regularity of the ozone fluctuation is more pronounced in IASI-a assimilation than in DM and MLS-a simulations. In addition to the influence of atmospheric dynamics, biomass burning and the associated ozone production could trigger the seasonal fluctuations. Such an ozone production detected by the 
(a) OMI-MLS
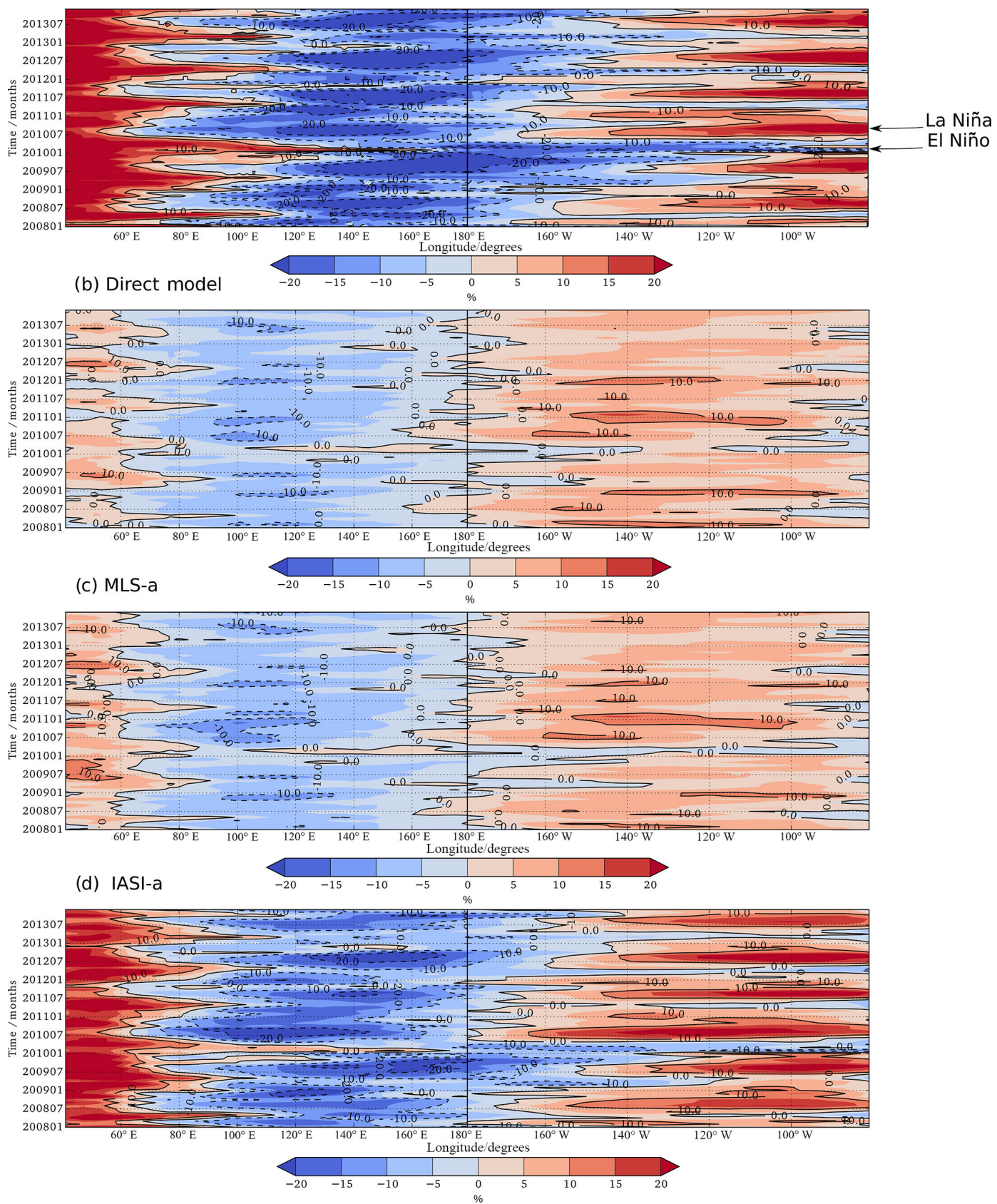

Figure 6. Longitude Hovmöller diagrams of TCO anomalies for (a) OMI-MLS measurements, (b) Direct Model, (c) MLS-a and (d) IASI-a between 2008 and 2013. Longitudes are identical to Fig. 5: between $40^{\circ} \mathrm{E}$ and $80^{\circ} \mathrm{W}$. Anomalies are expressed in percentage.

IASI instrument (and therefore visible in IASI-a) cannot be reproduced by the DM and MLS-a simulations due to the simplified chemical scheme.

Overall the combination of the IASI ozone tropospheric retrievals and our 4D-Var algorithm produces a very consistent dataset for the study of the influence of ENSO on the ozone distribution from the stratosphere to the middle troposphere. The quality of IASI-a, which also includes the as- similation of MLS, is good in the stratosphere down to the middle troposphere. In the boundary layer, below $800 \mathrm{hPa}$, a comprehensive chemical scheme with adequate emissions should be used to improve the assimilation since there are no global observations of the ozone content in this layer over the equatorial regions. 


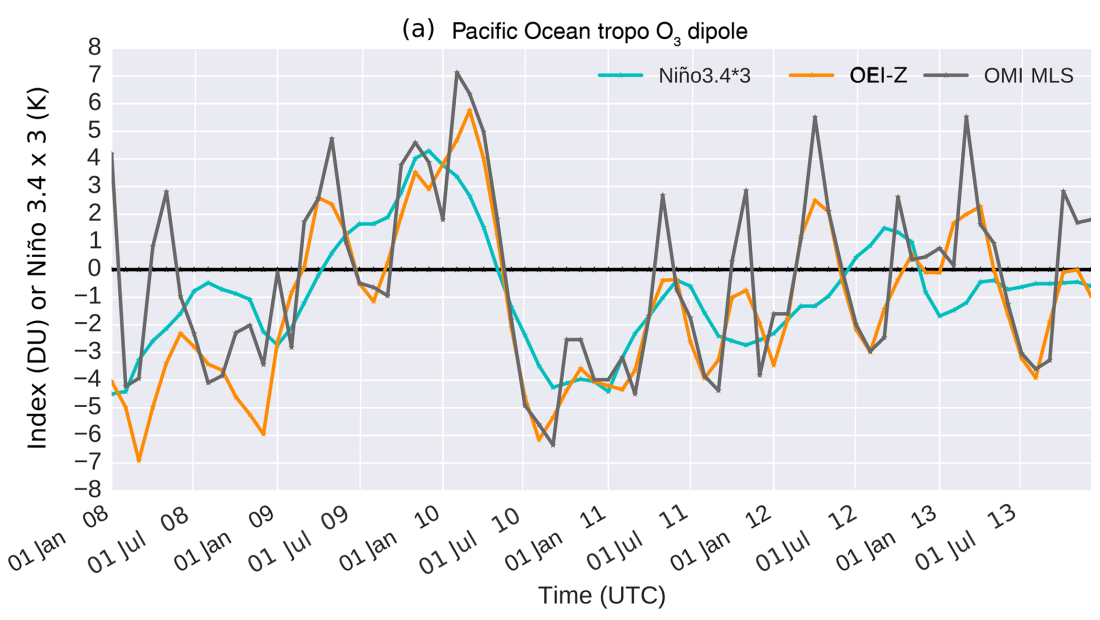

(b) Pacific Ocean tropo $\mathrm{O}_{3}$ dipole

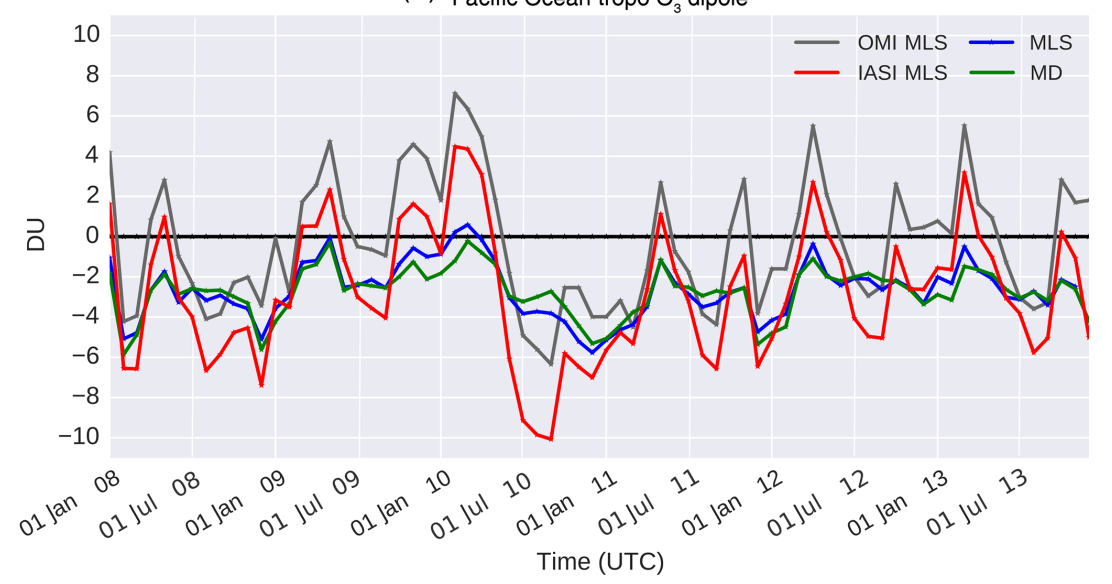

Figure 7. (a) Monthly mean tropospheric Ozone ENSO Index (in DU) derived from the OMI-MLS data (grey line). Also shown is the Niño 3.4 monthly temperature anomaly ENSO index (cyan curve, multiplied by a factor of 3, in Kelvin) and the OEI-Z index derived from the OMI-MLS data with a deseasonalization followed by a sliding average of 3 months (orange curve). (b) The OMI-MLS data (grey curve) as in the above plot, the MLS-a (in blue curve), the DM in green curve and the IASI-a (in red curve). All ENSO indices extend from January 2008 through December 2013.

\section{Summary and conclusion}

A total of 6 years (from January 2008 to December 2013) of 6-hourly tropospheric ozone fields have been derived by assimilating IASI and MLS ozone measurements in the MOCAGE CTM. The assimilation of IASI tropospheric columns combined with MLS stratospheric profiles was first validated against ozonesondes in the tropical band $\left(15^{\circ} \mathrm{S}-\right.$ $15^{\circ} \mathrm{N}$ ), providing a statistically robust validation. In the tropical band and over the whole period, IASI-a gives results similar to ozonesondes and reproduces the ozone variability well despite a constant bias. Biases in the analysis come from the low accuracy of the model in the boundary layer. The ozone linear scheme in MOCAGE does not take surface emissions into account. In addition, IASI has a weak sensitivity in the boundary layer and therefore does not provide additional information on $\mathrm{O}_{3}$ content in this layer. A second validation has been done over the Pacific ocean and over southern Asia (longitude band of $70^{\circ} \mathrm{E}$ to $110^{\circ} \mathrm{W}$ ). During the 2008-2013 period, an ENSO event developed with its two phases: El Niño in winter 2010 and La Niña in winter 2011. IASI-a has been validated in two areas: the Indonesia and Indian Ocean and the Pacific Ocean Center regions. In both regions, biases appear and are larger in the POC region. The weak sensitivity of IASI sounding in the boundary layer is responsible for these biases. However, the tropospheric ozone variability related to the Walker Circulation and to the ENSO event is well reproduced with IASI-a.

OMI-MLS tropospheric columns have been used and validated by several past studies. We have used OMI-MLS ozone data to characterize the links between SST and tropospheric $\mathrm{O}_{3}$ and to compare with our IASI-a assimilation. Anomalies of TCO have been computed, allowing a comparison between IASI-a and the two other simulations (Direct Model and MLS-a) with OMI-MLS. Anomalies of the Direct Model (MOCAGE without assimilation) are similar to 
(a) Direct model, IIO

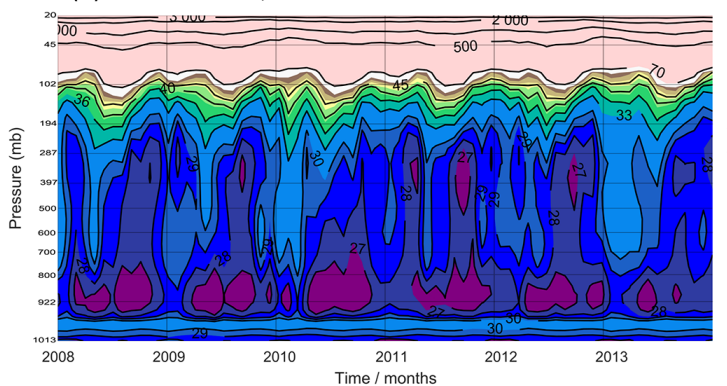

(c) MLS-a, IIO

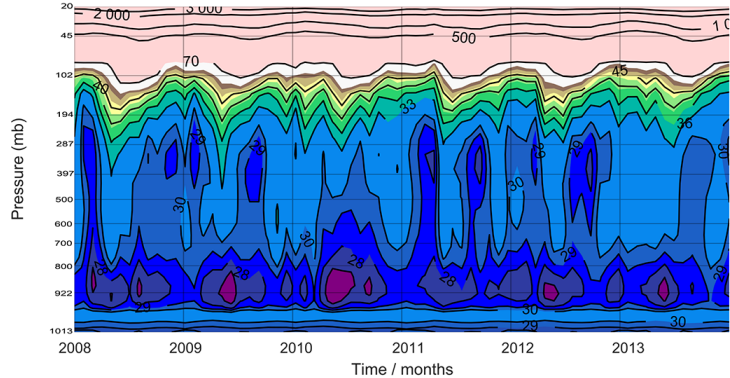

(e) IASI-a, IIO

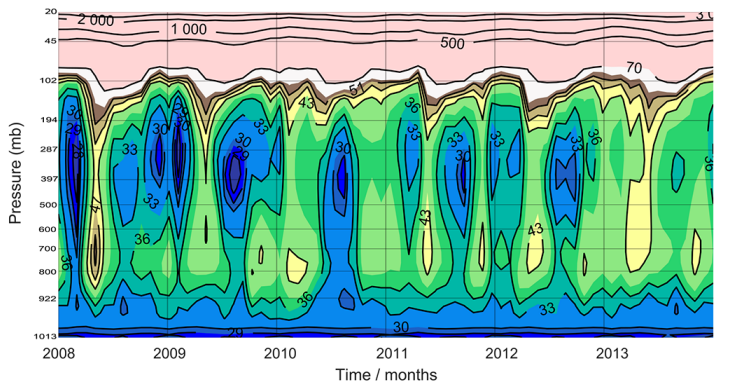

(b) Direct model, POC

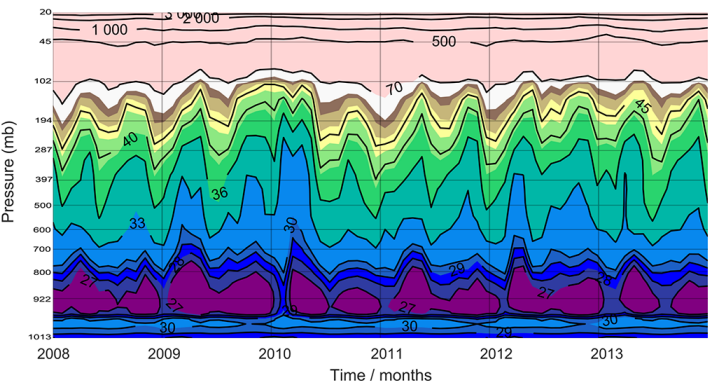

(d) MLS-a, POC

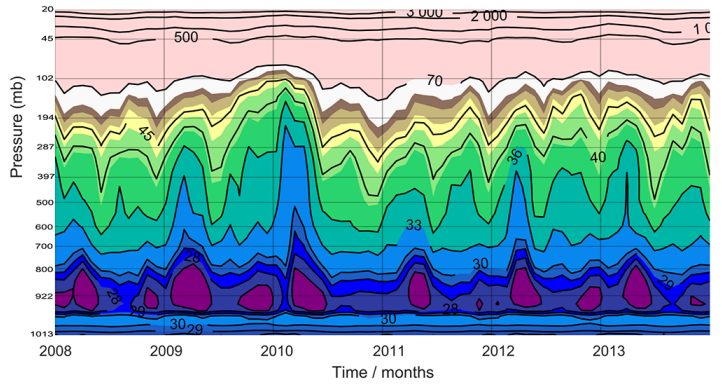

(f) IASI-a, POC

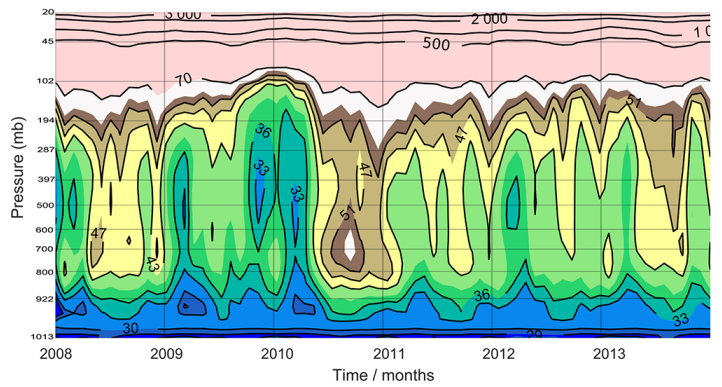

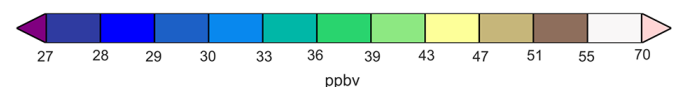

Figure 8. Monthly mean time series of ozone vertical profiles (units ppbv) versus pressure for the IIO region (a, c, e) and the POC region (b, d, f). The abscissa goes from January 2008 to December 2013. Panels (a, b) correspond to the Direct Model, (c, d) to the MLS-a and (e, f) to the IASI-a simulations. Pressure scale goes from 1013 to $20 \mathrm{hPa}$.

anomalies of MLS-a (assimilation of MLS stratospheric profiles). The good reproduction of anomalies in terms of location and timing between eastern and western regions in both simulations are due to the transport forced by the winds from the ECMWF meteorological analyses. However, the amplitude of anomalies is lower than in OMI-MLS data. Assimilation of IASI data corrects this behavior, and the anomalies of IASI-a appear very similar to the OMI-MLS anomalies. In particular, the IASI data bring essential information to reproduce the eastward shift of TCO caused by El Niño.

In order to study the ability of IASI-a to reproduce the ozone variability caused by El Niño and La Niña phases, we have used the OEI. The OEI represents an essential diagnostic test for models that should be able to represent ozone features linked with ENSO changes in tropospheric dynamics.
OEI from IASI-a shows variations similar to those of OMIMLS with a small bias corresponding to higher TCO over the POC than over the IIO region. The Direct Model and MLS-a have the same bias. This bias has been located in the boundary layer with the comparison with the ozonesondes.

We have also examined the vertical structures of tropospheric ozone in the IIO and POC regions, with the three simulations (Direct Model, MLS-a and IASI-a), in order to show the contribution of IASI tropospheric data in the assimilation. The IASI-a analysis is consistent with the ozone displacements in adequation with subsidences and convergences generated by El Niño and La Niña in both IIO and POC regions. The IASI assimilation gives a very valuable high-resolution dataset suitable to perform analyses of the 
$\mathrm{O}_{3}$ variability in the upper and middle troposphere for shortterm and interannual timescales in the tropical band.

Overall, the assimilation of stratospheric MLS and tropospheric IASI data within MOCAGE gives a good representation of the tropospheric ozone variability linked with ENSO and the Walker circulation. We have shown the importance of assimilating tropospheric IASI data to provide vertical information on tropospheric ozone variability, showing the benefit of IASI analyses for studies on ENSO dynamics. In addition, since ENSO is one of the most important interannual fluctuations in climate variability, this study is part of a climate variability perspective. The assimilation of satellite data is promising for determining the impact of climate variability on tropospheric chemistry. There are, however, some limitations in our simulations that have to be addressed. One of them is the bias found in the boundary layer over the Pacific Ocean that affects the calculation of the OEI. In this study we have used a linear ozone parameterization to compute the ozone chemical tendencies. This approach is suitable for the free troposphere and the stratosphere but is certainly not adequate for the boundary layers. In the future we plan to use a more comprehensive chemical scheme that accounts for the surface emissions.

With the use of IASI data we have demonstrated here the value of assimilating satellite data that document the direct information in the tropospheric ozone content to compute OEI. This approach is promising because many types of data can enter in an assimilation process, such as the balloon and aircraft measurements. Improvements in the tropospheric ozone content evaluations can be expected from an increase in assimilated data. Times series of IASI analysis could then be derived and used to study the tropospheric ozone variability over at least a 30 -year period. One advantage of infrared sounders like IASI for climate studies is their good spectral stability over time, with respect for example to UV instruments. This is an important feature when trying to determine potentially small climate signals hidden by large ozone variability, due for example to ENSO. Finally, using a more detailed chemistry scheme within future ozone reanalyses would also allow further insights into chemical feedbacks in the context of a changing climate.

Data availability. IASI L1 data were provided by the Laboratory of Aerology. EOS MLS L2 version 4 is available at https: $/ / \mathrm{mls}$.jpl.nasa.gov/data/. The OMI-MLS tropospheric ozone as well as the OEI-Z index are available at http://acd-ext.gsfc.nasa.gov/ Data_services/cloud_slice/. The Nino3.4 index is available from the NOAA website at http://www.cpc.ncep.noaa.gov/data/indices/.

Competing interests. The authors declare that they have no conflict of interest.
Acknowledgements. We would like to thank Jerry R. Ziemke and the Aura Ozone Monitoring Instrument (OMI) science team of the NASA Goddard Space Flight Center to the availability of the OMI-MLS data and the OEI-Z Index. We also thank WOUDC for providing ozonesonde station data and the NASA Jet Propulsion Laboratory for the availability of Aura MLS data. We also acknowledge the mission scientists from the NASA GES DISC, who provided the GIOVANNI SST data used in this research. In addition, we acknowledge la Région Midi-Pyrénées for financial support and the CNES (Centre National d'Études Spatiales) for financial sources on the TOSCA project. Thanks also to Sean Crowell for proofreading an earlier version of this paper.

Edited by: Jayanarayanan Kuttippurath

Reviewed by: Catherine Wespes and one anonymous referee

\section{References}

Andreae, M. O., Andreae, T. W., Annegarn, H., Beer, J., Cachier, H., Canut, P. L., Elbert, W., Maenhaut, W., Salma, I., Wienhold, F. G., and Zenker, T.: Airborne studies of aerosol emissions from savanna fires in southern Africa, J. Geophys. Res.-Space Phys., 103, 32119-32128, 1998.

Ardanuy, P. E. and Lee Kyle, H.: El Nino and Outgoing Longwave Radiation: Observations from Nimbus-7 ERB, Am. Meteorol. Soc., 114, 415-433, 1985.

Barnston, A. G., Chelliah, M., and Goldenberg, S. B.: Documentation of a Highly ENSO-related SST region in the Equatorial Pacific, Atmos. Ocean, 35, 367-383, 1997.

Barré, J., Peuch, V. H., Attié, J. L., El Amraoui, L., Lahoz, W. A., Josse, B., Claeyman, M., and Nédélec, P.: Stratosphere-troposphere ozone exchange from high resolution MLS ozone analyses, Atmos. Chem. Phys., 12, 6129-6144, https://doi.org/10.5194/acp-12-6129-2012, 2012.

Barré, J., Peuch, V.-H., Lahoz, W. A., Attié, J.-L., Josse, B., Piacentini, A., Eremenko, M., Dufour, G., Nedelec, P., von Clarmann, T., and El Amraoui, L.: Combined data assimilation of ozone tropospheric columns and stratospheric profiles in a high-resolution CTM, Q. J. Roy. Meteorol. Soc., 140, 966-981, https://doi.org/10.1002/qj.2176, 2013.

Barret, B., Le Flochmoen, E., Sauvage, B., Pavelin, E., Matricardi, M., and Cammas, J. P.: The detection of post-monsoon tropospheric ozone variability over south Asia using IASI data, Atmos. Chem. Phys., 11, 9533-9548, https://doi.org/10.5194/acp11-9533-2011, 2011.

Barret, B., Sauvage, B., Bennouna, Y., and Le Flochmoen, E.: Upper-tropospheric $\mathrm{CO}$ and $\mathrm{O}_{3}$ budget during the Asian summer monsoon, Atmos. Chem. Phys., 16, 9129-9147, https://doi.org/10.5194/acp-16-9129-2016, 2016.

Bell, M. L., McDermott, A., Zeger, S. L., Samet, J. M., and Dominici, F.: Ozone and mortality in 95 US urban communities, 1987 to 2000, JAMA, National Institutes of Health, 292, 23722378, https://doi.org/10.1001/jama.292.19.2372, 2004.

Berrisford, P., Dee, D. P., Poli, P., Brugge, R., Fielding, K., Fuentes, M., Kallberg, P. W., Kobayashi, S., Uppala, S., and Simmons, A.: The ERA-Interim archive Version 2.0, Shinfield Park, Reading, 2-22, 2011. 
Bousserez, N., Attié, J. L., Peuch, V. H., Michou, M., Pfister, G., Edwards, D., Emmons, L., Mari, C., Barret, B., Arnold, S. R., Heckel, A., Richter, A., Schlager, H., Lewis, A., Avery, M. A., Sachse, G. W., Browell, E. V., and Hair, J. W.: Evaluation of the MOCAGE chemistry transport model during the ICARTT/ITOP experiment, J. Geophys. Res.-Atmos., 112, 1-18, https://doi.org/10.1029/2006JD007595, 2007.

Cariolle, D. and Teyssèdre, H.: A revised linear ozone photochemistry parameterization for use in transport and general circulation models: multi-annual simulations, Atmos. Chem. Phys., 7, 2183 2196, https://doi.org/10.5194/acp-7-2183-2007, 2007.

Chandra, S., Ziemke, J. R., Min, W., and Read, W. G.: Effects of 1997-1998 El Nino on tropospheric ozone and water vapor, Geophys. Res. Lett., 25, 3867-3870, https://doi.org/10.1029/98g102695, 1998.

Chandra, S., Ziemke, J. R., Barthia, P. K., and Martin, R. V.: Tropical tropospheric ozone: Implications for dynamics and biomass burning, J. Geophys. Res., 107, https://doi.org/10.1029/2001JD000447, 2002.

Chandra, S., Ziemke, J. R., Duncan, B. N., Diehl, T. L., Livesey, N. J., and Froidevaux, L.: Effects of the 2006 El Niño on tropospheric ozone and carbon monoxide: implications for dynamics and biomass burning, Atmos. Chem. Phys., 9, 4239-4249, https://doi.org/10.5194/acp-9-4239-2009, 2009.

Clerbaux, C., Boynard, A., Clarisse, L., George, M., Hadji-Lazaro, J., Herbin, H., Hurtmans, D., Pommier, M., Razavi, A., Turquety, S., Wespes, C., and Coheur, P.-F.: Monitoring of atmospheric composition using the thermal infrared IASI/MetOp sounder, Atmos. Chem. Phys., 9, 6041-6054, https://doi.org/10.5194/acp-96041-2009, 2009.

Coheur, P.-F., Clarisse, L., Turquety, S., Hurtmans, D., and Clerbaux, C.: IASI measurements of reactive trace species in biomass burning plumes, Atmos. Chem. Phys., 9, 5655-5667, https://doi.org/10.5194/acp-9-5655-2009, 2009.

Cooper, O. R., Parrish, D. D., Ziemke, J., Balashov, N. V., Cupeiro, M., Galbally, I. E., Gilge, S., Horowitz, L., Jensen, N. R., Lamarque, J.-F., Naik, V., Oltmans, S. J., Schwab, J., Shindell, D. T., Thompson, a. M., Thouret, V., Wang, Y., and Zbinden, R. M.: Global distribution and trends of tropospheric ozone: An observation-based review, Elementa, 2, 2-29, https://doi.org/10.12952/journal.elementa.000029, 2014.

Craig, R.-A.: The upper atmosphere, meteorology and physics, Academic Press, 8, 23-25, 1965.

Curtis, S. and Adler, R.: ENSO indices based on patterns of satellite-derived precipitation, J. Climate, $13, \quad 2786-2793$, https://doi.org/10.1175/15200442(2000)013<2786:EIBOPO>2.0.CO;2, 2000.

Dobber, M. R., Dirksen, R. J., Levelt, P. F., Van Den Oord, G. H. J., Voors, R. H. M., Kleipool, Q., Jaross, G., Kowalewski, M., Hilsenrath, E., Leppelmeier, G. W., De Vries, J., Dierssen, W., and Rozemeijer, N. C.: Ozone monitoring instrument calibration, IEEE T. Geosci. Remote Sens., 44, 1209-1238, https://doi.org/10.1109/TGRS.2006.869987, 2006.

Doherty, R. M., Stevenson, D. S., Collins, W. J., and Sanderson, M. G.: Influence of convective transport on tropospheric ozone and its precursors in a chemistry-climate model, Atmos. Chem. Phys., 5, 3205-3218, https://doi.org/10.5194/acp-5-3205-2005, 2005.
Doherty, R. M., Stevenson, D. S., Johnson, C. E., Collins, W. J., and Sanderson, M. G.: Tropospheric ozone and El Niño-Southern Oscillation: Influence of atmospheric dynamics, biomass burning emissions, and future climate change, J. Geophys. Res., 111, 1-21, https://doi.org/10.1029/2005JD006849, 2006.

Dufour, G., Eremenko, M., Orphal, J., and Flaud, J.-M.: IASI observations of seasonal and day-to-day variations of tropospheric ozone over three highly populated areas of China: Beijing, Shanghai, and Hong Kong, Atmos. Chem. Phys., 10, $3787-$ 3801, https://doi.org/10.5194/acp-10-3787-2010, 2010.

Dufour, G., Eremenko, M., Griesfeller, A., Barret, B., LeFlochmoën, E., Clerbaux, C., Hadji-Lazaro, J., Coheur, P.-F., and Hurtmans, D.: Validation of three different scientific ozone products retrieved from IASI spectra using ozonesondes, Atmos. Meas. Tech., 5, 611-630, https://doi.org/10.5194/amt-5611-2012, 2012.

Ebi, K. L. and McGregor, G.: Climate change, tropospheric ozone and particulate matter, and health impacts, Environ. Health Perspect., 116, 1449-1455, https://doi.org/10.1289/ehp.11463, 2008.

El Amraoui, L., Attié, J., Semane, N., Claeyman, M., Peuch, V., Warner, J., Ricaud, P., Cammas, J., Piacentini, A., and Josse, B.: Midlatitude stratosphere-troposphere exchange as diagnosed by MLS $\mathrm{O}_{3}$ and MOPITT CO assimilated fields, Atmos. Chem. Phys., 10, 2175-2194, https://doi.org/10.5194/acp10-2175-2010, 2010.

Emili, E., Barret, B., Massart, S., Le Flochmoen, E., Piacentini, A., El Amraoui, L., Pannekoucke, O., and Cariolle, D.: Combined assimilation of IASI and MLS observations to constrain tropospheric and stratospheric ozone in a global chemical transport model, Atmos. Chem. Phys., 14, 177-198, https://doi.org/10.5194/acp-14-177-2014, 2014.

EOS MLS L2 version 4, available at: https://mls.jpl.nasa.gov/data/, 2017.

Fowler, D., Amann, M., Anderson, R., Ashmore, M., Cox, P., Depledge, M., Derwent, D., Grennfelt, P., Hewitt, N., Hov, O., Jenkin, M., Kelly, F., Liss, P., Pilling, M., Pyle, J., Slingo, J., and Stevenson, D.: Ground-level ozone in the 21st century: future trends, impacts and policy implications, October, The Royal Society, report 15/08, 2008.

Froidevaux, L., Jiang, Y. B., Lambert, A., Livesey, N. J., Read, W. G., Waters, J. W., Browell, E. V., Hair, J. W., Avery, M. A., McGee, T. J., Twigg, L. W., Sumnicht, G. K., Jucks, K. W., Margitan, J. J., Sen, B., Stachnik, R. A., Toon, G. C., Bernath, P. F., Boone, C. D., Walker, K. A., Filipiak, M. J., Harwood, R. S., Fuller, R. A., Manney, G. L., Schwartz, M. J., Daffer, W. H., Drouin, B. J., Cofield, R. E., Cuddy, D. T., Jarnot, R. F., Knosp, B. W., Perun, V. S., Snyder, W. V., Stek, P. C., Thurstans, R. P., and Wagner, P. A.: Validation of Aura Microwave Limb Sounder stratospheric ozone measurements, J. Geophys. Res.-Atmos., 113, D15S20, https://doi.org/10.1029/2007JD008771, 2008.

Geer, A. J., Lahoz, W. A., Bekki, S., Bormann, N., Errera, Q., Eskes, H. J., Fonteyn, D., Jackson, D. R., Juckes, M. N., Massart, S., Peuch, V. H., Rharmili, S., and Segers, A.: The ASSET intercomparison of ozone analyses: Method and first results, Atmos. Chem. Phys., 6, 5445-5474, https://doi.org/10.5194/acp-6-54452006, 2006.

Guilbert, J. J.: The world health report 2002 - reducing risks, promoting healthy life., Education for health (Abingdon, England), 
16, p. 230, https://doi.org/10.1080/1357628031000116808, 2003.

Herbin, H., Hurtmans, D., Clerbaux, C., Clarisse, L., and Coheur, P.-F.: $\mathrm{H}_{2}^{16} \mathrm{O}$ and HDO measurements with IASI/MetOp, Atmos. Chem. Phys., 9, 9433-9447, https://doi.org/10.5194/acp-9-94332009, 2009.

Honoré, C., Rouïl, L., Vautard, R., Beekmann, M., Bessagnet, B., Dufour, A., Elichegaray, C., Flaud, J. M., Malherbe, L., Meleux, F., Menut, L., Martin, D., Peuch, A., Peuch, V. H., and Poisson, N.: Predictability of European air quality: Assessment of 3 years of operational forecasts and analyses by the PREV'AIR system, J. Geophys. Res.-Atmos., 113, D04301, https://doi.org/10.1029/2007JD008761, 2008.

Houghton, J. T., Ding, Y., Griggs, D. J., Noguer, M., Van der Linden, P. J., Dai, X., Maskell, K., and Johnson, C. A.: Climate Change 2001: The Scientific Basis, Climate Change 2001: The Scientific Basis, 57, p. 881, https://doi.org/10.1256/004316502320517344, 2001.

Josse, B., Simon, P., and Peuch, V. H.: Radon global simulations with the multiscale chemistry and transport model MOCAGE, Tellus B, 56, 339-356, https://doi.org/10.1111/j.16000889.2004.00112.x, 2004.

Kim, J. H. and Newchurch, M. J.: Biomass-burning influence on tropospheric ozone over New Guinea and South America, J. Geophys. Res., 103, 1455-1461, https://doi.org/10.1029/97JD02294, 1998.

Lacis, A. A., Wuebbles, D. K., and Logan, J. A.: Radiative forcing of climate by changes in the vertical distribution of ozone, J. Geophys. Res, 95, 9971-9981, 1990.

Lee, S., Shelow, D. M., Thompson, A. M., and Miller, S. K.: QBO and ENSO variability in temperature and ozone from SHADOZ, 1998-2005, J. Geophys. Res., 115, D18105, https://doi.org/10.1029/2009JD013320, 2010.

Levelt, P. F., van den Oord, G. H. J., Dobber, M. R., Malkki, A., Visser, H., de Vries, J., Stammes, P., Lundell, J. O. V., and Saari, H.: The ozone monitoring instrument, IEEE T. Geosci. Remote Sens., 44, 1093-1101, 2006.

Liu, D. C. and Nocedal, J.: On the limited memory BFGS method for large scale optimization, Math. Program., 45, 503-528, https://doi.org/10.1007/BF01589116, 1989.

Liu, J., Rodriguez, J. M., Steenrod, S. D., Douglass, A. R., Logan, J. A., Olsen, M. A., Wargan, K., and Ziemke, J. R.: Causes of interannual variability over the southern hemispheric tropospheric ozone maximum, Atmos. Chem. Phys., 17, 3279-3299, https://doi.org/10.5194/acp-17-3279-2017, 2017.

Liu, X., Bhartia, P. K., Chance, K., Froidevaux, L., Spurr, R. J. D., and Kurosu, T. P.: Validation of Ozone Monitoring Instrument (OMI) ozone profiles and stratospheric ozone columns with Microwave Limb Sounder (MLS) measurements, Atmos. Chem. Phys., 10, 2539-2549, https://doi.org/10.5194/acp-102539-2010, 2010.

Livesey, N. J., Read, W. G., Froidevaux, L., Lambert, A., Manney, G. L., Pumphrey, H. C., Santee, M. L., Schwartz, M. J., Wang, S., Cofield, R. E., Cuddy, D. T., Fuller, R. A., Jarnot, R. F., Jiang, J. H., Knosp, B. W., Stek, P. C., Wagner, P. A., and Wu, D. L.: EOS MLS Version 3.3 Level 2 data quality and description document, Technical Report, Jet Propulsion Laboratory, 1-162, 2011.

Livesey, N. J., Read, W. G., Wagner, P. A., Froidevaux, L., Lambert, A., Manney, G. L., Millan Valle, L. F., Pumphrey, H. C., Santee,
M. L., Schwartz, M. J., Wang, R. A., Fuller, R. F., Jarnot, B. W., and Knosp, E. M.: EOS MLS Version $4.2 \times$ Level 2 data quality and description document, Tech. rep., 120-130, 2016.

Madden, R. A. and Julian, P. R.: Description of GlobalScale Circulation Cells in the Tropics with a 40-50 Day Period, 29, 1109-1123, https://doi.org/10.1175/15200469(1972)029<1109:DOGSCC >2.0CO;2, 1972.

Madden, R. A. and Julian, P. R.: Observations of the 40-50-Day Tropical Oscillation - A review., Mon. Weather Rev., 122, 814-837, https://doi.org/10.1175/15200493(1994)122<0814:OOTDTO>2.0.CO;2, 1994.

Marécal, V., Peuch, V. H., Andersson, C., Andersson, S., Arteta, J., Beekmann, M., Benedictow, A., Bergström, R., Bessagnet, B., Cansado, A., Chéroux, F., Colette, A., Coman, A., Curier, R. L., Van Der Gon, H. A., Drouin, A., Elbern, H., Emili, E., Engelen, R. J., Eskes, H. J., Foret, G., Friese, E., Gauss, M., Giannaros, C., Guth, J., Joly, M., Jaumouillé, E., Josse, B., Kadygrov, N., Kaiser, J. W., Krajsek, K., Kuenen, J., Kumar, U., Liora, N., Lopez, E., Malherbe, L., Martinez, I., Melas, D., Meleux, F., Menut, L., Moinat, P., Morales, T., Parmentier, J., Piacentini, A., Plu, M., Poupkou, A., Queguiner, S., Robertson, L., Rouïl, L., Schaap, M., Segers, A., Sofiev, M., Tarasson, L., Thomas, M., Timmermans, R., Valdebenito, Van Velthoven, P., Van Versendaal, R., Vira, J., and Ung, A.: A regional air quality forecasting system over Europe: The MACC-II daily ensemble production, Geosci. Model Dev., 8, 2777-2813, https://doi.org/10.5194/gmd-8-2777-2015, 2015.

Massart, S., Clerbaux, C., Cariolle, D., Piacentini, A., Turquety, S., and Hadji-Lazaro, J.: First steps towards the assimilation of IASI ozone data into the MOCAGE-PALM system, Atmos. Chem. Phys., 9, 5073-5091, https://doi.org/10.5194/acp-9-5073-2009, 2009.

Massart, S., Pajot, B., Piacentini, A., and Pannekoucke, O.: On the Merits of Using a 3D-FGAT Assimilation Scheme with an Outer Loop for Atmospheric Situations Governed by Transport, Mon. Weather Rev., 138, 4509-4522, https://doi.org/10.1175/2010MWR3237.1, 2010.

Matsueda, H., Taguchi, S., Inoue, H. Y., and Ishii, M.: A large impact of tropical biomass burning on $\mathrm{CO}$ and $\mathrm{CO}_{2}$ in the upper troposphere, Sci. China Series C, 45, 116-125, 2002.

Neu, J. L., Flury, T., Manney, G. L., Santee, M. L., Livesey, N. J., and Worden, J.: Tropospheric ozone variations governed by changes in stratospheric circulation, Nature Geosci., 7, 340344, https://doi.org/10.1038/NGEO2138, 2014.

Nino3.4 index, available at: http://www.cpc.ncep.noaa.gov/data/ indices/, 2017.

Oetjen, H., Payne, V. H., Neu, J. L., Kulawik, S. S., Edwards, D. P., Eldering, A., Worden, H. M., and Worden, J. R.: A joint data record of tropospheric ozone from Aura-TES and MetOp-IASI, Atmos. Chem. Phys., 16, 10 229-10239, https://doi.org/10.5194/acp-16-10229-2016, 2016.

Olsen, M. A., Wargan, K., and Pawson, S.: Tropospheric column ozone response to ENSO in GEOS-5 assimilation of OMI and MLS ozone data, Atmos. Chem. Phys., 16, 7091-7103, https://doi.org/10.5194/acp-16-7091-2016, 2016.

Oman, L. D., Ziemke, J. R., Douglass, A. R., Waugh, D. W., Lang, C., Rodriguez, J. M., and Nielsen, J. E.: The response of tropical tropospheric ozone to ENSO, Geophys. Res. Lett., 38, 2-7, https://doi.org/10.1029/2011GL047865, 2011. 
Oman, L. D., Douglass, A. R., Ziemke, J. R., Rodriguez, J. M., Waugh, D. W., and Nielsen, J. E.: The ozone response to enso in aura satellite measurements and a chemistryclimate simulation, J. Geophys. Res.-Atmos., 118, 965-976, https://doi.org/10.1029/2012JD018546, 2013.

OMI-MLS/OEI-Z index, available at: http://acd-ext.gsfc.nasa.gov/ Data_services/cloud_slice/, 2017.

Pavelin, E. G., English, S. J., and Eyre, J. R.: The assimilation of cloud-affected infrared satellite radiances for numerical weather prediction, Q. J. Roy. Meteorol. Soc., 134, 737-749, https://doi.org/10.1002/qj.243, 2008.

Philander, S. G.: El Niño, La Nina, and the Southern Oscillation, Academic Press, 46, 289-293, 1989.

Pittman, J. V., Pan, L. L., Wei, J. C., Irion, F. W., Liu, X., Maddy, E. S., Barnet, C. D., Chance, K., and Gao, R. S.: Evaluation of AIRS, IASI, and OMI ozone profile retrievals in the extratropical tropopause region using in situ aircraft measurements, J. Geophys. Res.-Atmos., 114, 1-17, https://doi.org/10.1029/2009JD012493, 2009.

Quan, X.-W., Diaz, H. F., and Hoerling, M. P.: Change of the Tropical Hadley Cell Since 1950, The Hadley Circulation: Present, Past and Future, 85-120, https://doi.org/10.1007/978-1-40202944-8_4, 2004.

Randel, W. J. and Thompson, A. M.: Interannual variability and trends in tropical ozone derived from SAGE II satellite data and SHADOZ ozonesondes, J. Geophys. Res., 116, D07303, https://doi.org/10.1029/2010JD015195, 2011.

Safieddine, S., Clerbaux, C., George, M., Hadji-Lazaro, J., Hurtmans, D., Coheur, P. F., Wespes, C., Loyola, D., Valks, P., and Hao, N.: Tropospheric ozone and nitrogen dioxide measurements in urban and rural regions as seen by IASI and GOME-2, J. Geophys. Res.-Atmos., 118, 10555-10566, https://doi.org/10.1002/jgrd.50669, 2013.

Saunders, R., Matricardi, M., and Brunel, P.: An improved fast radiative transfer model for assimilation of satellite radiance observations, Q. J. Roy. Meteorol. Soc., 125, 1407-1425, 1999a.

Saunders, R., Matricardi, M., and Brunel, P.: A fast radiative transfer model for assimilation of satellite radiance observations RTTOV-5, ECMWF - Technical Memorandum, 1999b.

Scannell, C., Hurtmans, D., Boynard, A., Hadji-Lazaro, J., George, M., Delcloo, A., Tuinder, O., Coheur, P.-F., and Clerbaux, C.: Antarctic ozone hole as observed by IASI/MetOp for 2008-2010, Atmos. Meas. Tech., 5, 123-139, https://doi.org/10.5194/amt-5123-2012, 2012.

Schwartz, M., Froidevaux, L., Livesey, N., and Read, W.: MLS/Aura Level 2 Ozone $\left(\mathrm{O}_{3}\right)$ Mixing Ratio V004, Goddard Earth Sciences Data and Information Services Center (GES DISC), 2015.

Sič, B., El Amraoui, L., Marécal, V., Josse, B., Arteta, J., Guth, J., Joly, M., and Hamer, P. D.: Modelling of primary aerosols in the chemical transport model MOCAGE: Development and evaluation of aerosol physical parameterizations, Geosci. Model Dev., 8, 381-408, https://doi.org/10.5194/gmd-8-381-2015, 2015.

Sič, B., El Amraoui, L., Piacentini, A., Marécal, V., Emili, E., Cariolle, D., Prather, M., and Attie, J. L.: Aerosol data assimilation in the chemical transport model MOCAGE during the TRAQA/ChArMEx campaign: Aerosol optical depth, Atmos. Meas. Tech., 9, 5535-5554, https://doi.org/10.5194/amt-9-55352016, 2016.
Sinha, P., Jaeglé, L., Hobbs, P. V., and Liang, Q.: Transport of biomass burning emissions from southern Africa, J. Geophys. Res.-Atmos., 109, 1-15, https://doi.org/10.1029/2004JD005044, 2004.

Solomon, S., Thompson, D. W. J., Portmann, R. W., Oltmans, S. J., and Thompson, a. M.: On the distribution and variability of ozone in the tropical upper troposphere: Implications for tropical deep convection and chemical-dynamical coupling, Geophys Res. Lett., 32, L23813, https://doi.org/10.1029/2005GL024323, 2005 .

Stevenson, D., Doherty, R., Sanderson, M., Johnson, C., and Derwent, R. G.: Impacts of climate change and variability on tropospheric ozone and its precursors, Faraday Discuss., 130, 41-57, https://doi.org/10.1039/b417412g, 2005.

Streets, D. G., Yarber, K. F., Woo, J.-H., and Carmichael, G. R.: Biomass burning in Asia: Annual and seasonal estimates and atmospheric emissions, Global Biogeochem. Cy., 17, 1099, https://doi.org/10.1029/2003GB002040, 2003.

Sudo, K. and Takahashi, M.: Simulation of tropospheric ozone changes during 1997-1998 El Nino: Meteorological impact on tropospheric photochemistry, Geophys. Res. Lett., 28, 40914094, https://doi.org/10.1029/2001GL013335, 2001.

Teyssèdre, H., Michou, M., Clark, H. L., Josse, B., Karcher, F., Olivié, D., Peuch, V.-H., Saint-Martin, D., Cariolle, D., Attié, J.-L., Nédélec, P., Ricaud, P., Thouret, V., van der A, R. J., VolzThomas, A., and Chéroux, F.: A new tropospheric and stratospheric Chemistry and Transport Model MOCAGE-Climat for multi-year studies: evaluation of the present-day climatology and sensitivity to surface processes, Atmos. Chem. Phys., 7, 58155860, https://doi.org/10.5194/acp-7-5815-2007, 2007.

Thompson, A. M., Witte, J. C., McPeters, R. D., Oltmans, S. J., Schmidlin, F. J., Logan, J. A., Fujiwara, M., Kirchhoff, V. W. J. H., Posny, F., Coetzee, G. J. R., Hoegger, B., Kawakami, S., Ogaawa, T., Johnson, B. J., Vomel, H., and Labow, G.: Southern Hemisphere Additional Ozonesondes (SHADOZ) 1998-2000 tropical ozone climatology 1. Comparaison with Total Ozone Mapping Spectrometer and ground-based measurements, J. Geophys. Res., 108, 8241, https://doi.org/10.1029/2002JD002241, 2003.

Tocquer, F., Barret, B., Mari, C., Flochmoën, E. L. E., Cammas, J. P., and Sauvage, B.: An upper tropospheric 'ozone river' from Africa to India during the 2008 Asian post-monsoon season, Tellus B, 67, https://doi.org/10.3402/tellusb.v67.25350, 2015.

Toihir, A. M., Bencherif, H., Sivakumar, V., El Amraoui, L., Portafaix, T., and Mbatha, N.: Comparison of total column ozone obtained by the IASI-MetOp satellite with ground-based and OMI satellite observations in the southern tropics and subtropics, Ann. Geophys., 33, 1135-1146, https://doi.org/10.5194/angeo33-1135-2015, 2015.

Trenberth, K. E.: The Definition of El Nino, Bulletin of the Am. Meteorol. Soc., 78, 2771-2777, https://doi.org/10.1175/1520 0477(1997)078<2771:TDOENO>2.0.CO;2, 1997.

Wang, W., Pinto, J. P., and Yung, Y. L.: Greenhouse effects due to man-made perturbations of trace gases, J. Atmos. Sci., 97, 333 338, 1980.

Wang, X. L., Rui, H. L., and Leetmaa, A.: The Dynamics of ENSO Anomaly as Revealed in Ensemble Climate SimulationsImpact of Mean Stationary Wave, Adv. Atmos. Sci., 13, 425444, https://doi.org/10.1007/BF03342035, 2014. 
Waters, J. W., Froidevaux, L., Harwood, R. S., Jarnot, R. F., Pickett, H. M., Read, W. G., Siegel, P. H., Cofield, R. E., Filipiak, M. J., Flower, D. A., Holden, J. R., Lau, G. K., Livesey, N. J., Manney, G. L., Pumphrey, H. C., Santee, M. L., Wu, D. L., Cuddy, D. T., Lay, R. R., Loo, M. S., Perun, V. S., Schwartz, M. J., Stek, P. C., Thurstans, R. P., Boyles, M. A., Chandra, K. M., Chavez, M. C., Chen, G. S., Chudasama, B. V., Dodge, R., Fuller, R. A., Girard, M. A., Jiang, J. H., Jiang, Y., Knosp, B. W., Labelle, R. C., Lam, J. C., Lee, K. A., Miller, D., Oswald, J. E., Patel, N. C., Pukala, D. M., Quintero, O., Scaff, D. M., Van Snyder, W., Tope, M. C., Wagner, P. A., and Walch, M. J.: The Earth Observing System Microwave Limb Sounder (EOS MLS) on the aura satellite, IEEE T. Geosci. Remote Sens., 44, 1075-1092, https://doi.org/10.1109/TGRS.2006.873771, 2006.

Weaver, A. and Courtier, P.: Correlation modelling on the sphere using a generalized diffusion equation, Q. J. Roy. Meteorol. Soc., 127, 1815-1846, https://doi.org/10.1002/qj.49712757518, 2001.

Wespes, C., Hurtmans, D., Clerbaux, C., Santee, M. L., Martin, R. V., and Coheur, P. F.: Global distributions of nitric acid from IASI/MetOP measurements, Atmos. Chem. Phys., 9, 7949-7962, https://doi.org/10.5194/acp-9-7949-2009, 2009.

Wespes, C., Emmons, L., Edwards, D. P., Hannigan, J., Hurtmans, D., Saunois, M., Coheur, P. F., Clerbaux, C., Coffey, M. T., Batchelor, R. L., Lindenmaier, R., Strong, K., Weinheimer, A. J., Nowak, J. B., Ryerson, T. B., Crounse, J. D., and Wennberg, P. O.: Analysis of ozone and nitric acid in spring and summer Arctic pollution using aircraft, ground-based, satellite observations and MOZART-4 model: Source attribution and partitioning, Atmos. Chem. Phys., 12, 237-259, https://doi.org/10.5194/acp12-237-2012, 2012.

Wespes, C., Hurtmans, D., K Emmons, L., Safieddine, S., Clerbaux, C., Edwards, D. P., and Coheur, P. F.: Ozone variability in the troposphere and the stratosphere from the first 6 years of IASI observations (2008-2013), Atmos. Chem. Phys., 16, 5721-5743, https://doi.org/10.5194/acp-16-5721-2016, 2016.

Wespes, C., Hurtmans, D., Clerbaux, C., and Coheur, P.-F.: $\mathrm{O}_{3}$ variablity in the troposphere as observed by IASI over 2008-2016: Contribution of atmospheric chemistry and dynamics, J. Geophys. Res., 122, 2429-2451, https://doi.org/10.1002/2016JD025875, 2017.

Williamson, D. L. and Rasch, P. J.: Two-dimensional semilagrangian transport with shape-preserving interpolation, Mon. Weather Rev., 117, 102-129, 1989.
Yendrek, C. R., Koester, R. P., and Ainsworth, E. A.: A comparative analysis of transcriptomic, biochemical, and physiological responses to elevated ozone identifies species-specific mechanisms of resilience in legume crops, J. Exp. Bot., 66, 7101-7112, https://doi.org/10.1093/jxb/erv404, 2015.

Zeng, G. and Pyle, J. A.: Influence of El Nino Southern Oscillation on stratosphere/troposphere exchange and the global tropospheric ozone budget, Geophys. Res. Lett., 32, 1-4, https://doi.org/10.1029/2004GL021353, 2005.

Ziemke, J. R., Chandra, S., and Bhartia, P. K.: Two new methods for deriving tropospheric column ozone from TOMS measurements: Assimilated UARS MLS/HALOE and convective-cloud differential techniques, J. Geophys. Res.-Atmos., 103, 22115-22127, https://doi.org/10.1029/98JD01567, 1998.

Ziemke, J. R., Chandra, S., Duncan, B. N., Froidevaux, L., Bhartia, P. K., Levelt, P. F., and Waters, J. W.: Tropospheric ozone determined from Aura OMI and MLS: Evaluation of measurements and comparison with the Global Modeling Initiative's Chemical Transport Model, J. Geophys. Res., 111, D19303, https://doi.org/10.1029/2006JD007089, 2006.

Ziemke, J. R., Chandra, S., Oman, L. D., and Bhartia, P. K.: A new ENSO index derived from satellite measurements of column ozone, Atmos. Chem. Phys., 10, 3711-3721, https://doi.org/10.5194/acp-10-3711-2010, 2010.

Ziemke, J. R., Olsen, M. A., Witte, J. C., Douglass, A. R., Strahan, S. E., Wargan, K., Liu, X., Schoeberl, M. R., Yang, K., Kaplan, T. B., Pawson, S., Duncan, B. N., Newman, P. A., Hartia, P. K., and Heney, M. K.: Assessment and applications of NASA ozone data products derived from Aura OMI/MLS satellite measurements in context of the GMI chemical transport model, Geophys. Res. Lett., 119, 1-14, https://doi.org/10.1002/2014JD021494, 2014.

Ziemke, J. R., Douglass, a. R., Oman, L. D., Strahan, S. E., and Duncan, B. N.: Tropospheric ozone variability in the tropics from ENSO to MJO and shorter timescales, Atmos. Chem. Phys., 15, 8037-8049, https://doi.org/10.5194/acp-15-8037-2015, 2015.

Ziemke, J. R. and Chandra, S.: La Nina and El Ninoinduced variabilities of ozone in the tropical lower atmosphere during 1970-2001, Geophys. Res. Lett., 30, 1142, https://doi.org/10.1029/2002GL016387, 2003. 